IZA DP No. 8933

Gender Differences in the Distribution of Total Work-Time of Latin-American Families:

The Importance of Social Norms

Juan Carlos Campaña

J. Ignacio Gimenez-Nadal

Jose Alberto Molina

March 2015 


\title{
Gender Differences in the Distribution of Total Work-Time of Latin-American Families: The Importance of Social Norms
}

\author{
Juan Carlos Campaña \\ University of Zaragoza
}

J. Ignacio Gimenez-Nadal

University of Zaragoza and CTUR

Jose Alberto Molina

University of Zaragoza and IZA

Discussion Paper No. 8933

March 2015

\author{
IZA \\ P.O. Box 7240 \\ 53072 Bonn \\ Germany \\ Phone: +49-228-3894-0 \\ Fax: +49-228-3894-180 \\ E-mail: iza@iza.org
}

\begin{abstract}
Any opinions expressed here are those of the author(s) and not those of IZA. Research published in this series may include views on policy, but the institute itself takes no institutional policy positions. The IZA research network is committed to the IZA Guiding Principles of Research Integrity.

The Institute for the Study of Labor (IZA) in Bonn is a local and virtual international research center and a place of communication between science, politics and business. IZA is an independent nonprofit organization supported by Deutsche Post Foundation. The center is associated with the University of Bonn and offers a stimulating research environment through its international network, workshops and conferences, data service, project support, research visits and doctoral program. IZA engages in (i) original and internationally competitive research in all fields of labor economics, (ii) development of policy concepts, and (iii) dissemination of research results and concepts to the interested public.
\end{abstract}

IZA Discussion Papers often represent preliminary work and are circulated to encourage discussion. Citation of such a paper should account for its provisional character. A revised version may be available directly from the author. 


\title{
ABSTRACT \\ Gender Differences in the Distribution of Total Work-Time of Latin-American Families: The Importance of Social Norms ${ }^{*}$
}

\begin{abstract}
We analyze differences by gender in the time dedicated to total work (paid and unpaid) by families in Latin America, with particular attention to the effect of social norms. To this end, we use survey data on time use in Mexico (2009), Peru (2010), Ecuador (2012) and Colombia (2012), to estimate differential equations through OLS. Our results reveal differences between countries in terms of the gender distribution of total work (paid work plus unpaid work), with Colombia and Peru being more equitable. These two countries could be approaching a situation of "iso-work", or equality of work, in the sense that men and women spend similar amounts of time in total work. When considering the social norms that explain gender differences in the time spent in total work, we use data from the last wave (20102014) of the World Values Survey (WVS). Our results indicate that the more egalitarian countries exhibit the highest levels of equality in the distribution of work. It is important to know how men and women from these four countries distribute their time in total work, in order to understand why there are clear differences by gender.
\end{abstract}

JEL Classification: D13, J22, J13, J16

Keywords: $\quad$ total work, Latin America, differences by gender, social norms

Corresponding author:

Ignacio Gimenez Nadal

Department of Economic Analysis

University of Zaragoza

C/ Gran Via 2

50005 - Zaragoza

Spain

E-mail: ngimenez@unizar.es

\footnotetext{
* This paper was partially written while Jose Alberto Molina was Visiting Fellow at the Department of Economics of the Boston College (US), to which he would like to express his thanks for the hospitality and facilities provided. This paper has benefited from funding from the Spanish Ministry of Economics (Project ECO2012-34828).
} 


\section{Introduction}

This study aims to analyze the differences in the time spent in total work (paid and unpaid) in four Latin-American countries. This is an important issue, since this time can be converted into money, goods, and services, which then increases consumption. Analysis of this time use will provide us with an overview of production as consumption (Fleming and Spellerberg, 1999). Furthermore, knowing the total work time of men and women will provide us with a knowledge of the time spent on leisure. Total work and leisure time are the two crucial points when discussing the so-called "gender wars" (Burda et al., 2007). It should be noted, moreover, that differences in how individuals use their time in paid and unpaid work may have implications for their daily well-being (Kahneman et al., 2004; Kahneman and Kruger, 2006; Kruger, 2007). We conduct an analysis of families in Mexico, Peru, Colombia and Ecuador that will give us an approximate view of the allocation of time in total work, for both men and women.

The majority of economic investigations in Latin America have focused on studying time spent in paid, or market work. As indicated by Burda, et al (2013), gender differentials continue to be largely ignored by economists in the study of time dedicated to total work, despite the obvious importance of looking at how people spend their time outside the labour market. One probable cause of this oversight has been the lack of available data, but this has begun to change, especially in developed countries, with more cross-country comparisons beginning to appear (Gimenez-Nadal and Sevilla, 2012; Burda et al., 2007, 2008, 2013).

In Latin-America, we find very limited evidence regarding the gender division of housework and market work. Canelas and Salazar (2014), using a variety of polls for Ecuador, Guatemala and Bolivia, conclude that, relative to men, women are discriminated against in the labour market and are burdened with the bulk of domestic household activities. To overcome the limitations of the available, heterogeneous data, in our work we provide information on four Latin-American countries, using, as a homogeneous source of data, surveys of time use in similar time periods.

To draw our comparisons, we analyse data from surveys of time use in Mexico (2009), Peru (2010), Colombia (2012), and Ecuador (2012), with respect to the uses of time spent in paid work, domestic work, childcare, and total work. We find that men in these four countries spend more time in paid work, while the women spend more time in chores and childcare. Men in Peru spend the most time in paid work, 50.93 hours per week, compared to 
Ecuador, Mexico, and Colombia, at 48.57, 49.68 and 46.91 weekly hours, respectively. Women in Mexico spend the most hours in housework, 38.91 hours per week, compared to women in Ecuador, Peru, and Colombia, at 37.54, 37.69 and 31.61 weekly hours, respectively. Women in Ecuadorian spend the most time in childcare, at 6.43 hours a week, compared to Mexico, Peru, and Colombia with 5.13, 5.48, and 4.88 hours per week, respectively.

Based on this evidence, we have combined paid work, housework and caring for children into a single activity, total work. In Ecuador and Mexico, we find quite marked differences between men and women, in favour of men: 7.34 and 3.70 hours per week, respectively, while Peru and Colombia display less discriminating behaviour. In Peru, the gender gap for women is 1.66 hours per week, and in Colombia, men devote 0.46 more hours per week to total work than do women. We use social norms as one possible explanation for the reasons behind these gender differentials. Burda et al., (2013) consider that social standards serve as a device to coordinate total work between men and women. More traditional social norms dictate that women bear the heaviest burden of total work, which, in turn, acts as a drag on economic development. To measure the effect of social standards in the four countries studied, we use information from the last wave of the world values survey (WVS, 20102014) and construct an egalitarian index, following Alessina and Giuliano (2007) and Sevilla (2010), to determine which countries are more - or less - egalitarian countries. Our results confirm that the more egalitarian the country, the smaller the gender gap in total work. Considering the importance of social norms and how they influence the distribution of total work, we carry out regressions via OLS, with our results confirming that cross-country gender differences disappearing with the growth of gender equality.

In this context, we analyze heterogeneous groups within each country, as have other studies of time use (Gimenez-Nadal and Sevilla, 2014), determining three levels of education (primary, secondary, and University) and considering the presence or absence of children at home. Our results show that more egalitarian social norms tend to have a greater effect in reducing gender differences when there are no children in the home, but are less efficacious when children are present. This can be explained by the difficulties imposed by the labour market on women with children (Mateo Diaz and Rodriguez-Chamussy, 2013) and the prevailing limitations on the services offered for childcare (Araujo et al, 2013).

Section 2 presents our theoretical framework, Section 3 contains a review of the relevant literature, and Section 4 describes our data and variables, and trends in total work in the four 
countries studied. In Section 5 we deal with the relevant social norms, and Section 6 presents our descriptive results, identified by socio-demographic groups, as well as other country evidence. Our econometric analysis and empirical results comprise Section 7, and Section 8 summarizes our conclusions and policy recommendations.

\section{Theoretical Framework}

Our theoretical framework is based on Gimenez-Nadal and Sevilla (2014), who establish that time spent in total work is represented as:

$$
\mathrm{TWm}=\varepsilon \mathrm{W}^{\mathrm{m}} \text { and } \mathrm{TW}^{\mathrm{f}}=\varepsilon \mathrm{w}^{\mathrm{f}} \text {, }
$$

where " $\mathrm{m}$ " is male and "f" is female, and where we assume that the sensitivity of work to the wage rate " $\mathrm{w}$ " is equal across genders in each country. Focusing on gender differences in total work we obtain:

$T W^{m}-T W^{f}=W^{m}-\varepsilon^{f} W=\varepsilon \varepsilon\left(W^{m}-W^{-}{ }^{f}\right)$.

In Australia, the Netherlands, and Norway, men devote more time to overall work (GimenezNadal and Sevilla, 2012), in the Mediterranean countries they spend less time in total work than women (Burda et al., 2007).

Thus, we consider the existence of a social/gender norm in a given country that influences individual time in total work, defined as the mean time men $\left(\mathrm{TW}^{\mathrm{m}}{ }^{*}\right)$ and women $\left(\mathrm{TW}^{\mathrm{f}}{ }^{*}\right)$ should devote to total work. We measure the strength of the social norm regarding total work as, $0 \leq \phi \leq \infty$, where $\phi=0$ indicates that there is no binding social/gender norm and thus agents choose TW $=\varepsilon \mathrm{w}$, whereas when $\varepsilon \phi=\infty$, the social/gender norm is infinitely powerful and obligates individuals to choose $\mathrm{TW}^{\mathrm{m}}=\mathrm{TW}^{\mathrm{m}}{ }^{*}$ and $\mathrm{TW}^{\mathrm{f}}=\mathrm{TW}^{\mathrm{f}}{ }^{*}$. For $\phi$ between 0 and $\infty$, the social/gender norm pulls total optimal choice away from work TW $=\varepsilon w$ towards $\mathrm{TW}^{*}$, and hence:

$\mathrm{TW}^{\mathrm{m}}=\alpha\left(\mathrm{EW}^{\mathrm{m}}\right)+(1-\alpha) \mathrm{TW}^{\mathrm{m}} *$

$\mathrm{TW}^{\mathrm{f}}=\alpha\left(\mathrm{EW}^{\mathrm{f}}\right)+(1-\alpha) \mathrm{TW}^{\mathrm{f}}$

with the weight $0 \leq \alpha \leq 1$ and defined as $\alpha=1 / 1+\Phi \varepsilon$. We establish a negative relationship between $\alpha$ and $\phi$. If $\phi=0, \alpha=1$, indicating that there is no binding social/gender norm and individuals choose freely their total work time, according to TW= $\varepsilon \mathrm{W}$. If $\phi=\infty, \alpha=0$, 
indicating that the social/gender norm is infinitely powerful and obligates individuals to choose $\mathrm{TW}^{\mathrm{m}}=\mathrm{TW}^{\mathrm{m}}{ }^{*}$ and $\mathrm{TW}^{\mathrm{f}}=\mathrm{TW}^{\mathrm{f}}$.

Focusing on gender differences in total work time, we obtain:

$T W^{m}-T W^{f}=\alpha \varepsilon\left(W^{m}-W^{-}{ }^{f}\right)+(1-\alpha)\left(T W^{m *}-T W^{f *}\right)$

If $\alpha=1$, we could consider that there is no social/gender norm, and thus the gender difference in total work can be explained by $\mathrm{TW}^{\mathrm{m}}-\mathrm{TW}^{\mathrm{f}}=\varepsilon\left(\mathrm{W}^{\mathrm{m}}-\mathrm{W}^{-}{ }^{\mathrm{f}}\right)$. Sevilla (2010) carries out a classification of 13 countries, from more to less egalitarian, showing how social norms influence the behavior of men and women, depending on countries. While countries of northern Europe, including Sweden and Norway, would be considered more egalitarian countries (approximate $\alpha=1$ ), countries of southern Europe, such as Spain, would be framed as being less egalitarian $(\alpha<1)$, thus explaining why social norms have an effect on total work time (see Garcia et al., 2010 and 2011, and Molina and Montuenga, 2009, on gender differences in time spent at work and on childcare in Spain).

\section{Background}

Over the past three decades one of the most significant changes in Latin-America has been the growing economic contribution of women in the region, due mainly to millions of women having entered the labour market. The rate of female labour participation on the Mainland increased from 35\% in 1980 to 53\% in 2007 (Pages and Piras, 2010) and between 30\% and $40 \%$ of the increase in the labor force participation of women is due to changes related to educational level (Duryea et al 2004). Despite these increases in the labor force participation of women, specialization within the household has changed very little in recent decades. According to Folbre (2006), in Latin America, as in the Caribbean, the primary responsibility for the care of the sick, the elderly, and children still falls on women. While this creates well-being for households, it imposes costs on, and substantial limitations to, the female members of the family.

There is evidence from other countries. Sevilla et al., (2010), show how between 1980 and 2000 in the developed world, women doubled their participation in the labour market, from $22 \%$ to $44 \%$. However, despite this increase, the proportion of the time devoted by women to domestic tasks and childcare has hardly changed in the same time frame (see Figure 1). As seen in Baxter (2002), Bianchi (2000), and Bittman (1999), despite the increase of women in 
the labour market, they still specialized in unpaid work. Regarding the participation of men in the home, the increase for men in housework time has been modest, to say the least. Thus, specialization in chores has undergone little change (Gershuny, 2000, and Bianchi et al., 2006). More evidence exists of the so-called second shift, that is, when the woman works outside the home for more hours than her husband, she still carries the greater burden of housework (Hochshild and Machung, 1989). In recent decades, differences in the distribution of the time spent in total work (paid and unpaid work) has become somewhat more equal, especially in the developed countries, even getting to the point where some men carry more of the load of total work than women (see Giménez-Nadal and Sevilla, 2012).

Burda et al., (2013) point out that, even though men spend more time in the labour market, and women are more involved in home production, the inter-gender distribution of total work is equal in certain countries. Comparing the Catholic and non-Catholic developed countries; these authors show that, in the case of the non-Catholic countries, total work time is nearly equal by gender, while women in Catholic countries invest more time in total work. In general, in the 27 developed countries studied (Catholic and non-Catholic) the total workload is greater for women than for men. However, when the sample is restricted to non-Catholic countries, then the time dedicated to total work is almost the same for men and women, indicating that social norms can partially influence partially the results. This phenomenon, where the distribution of total work is equal between men and women is known as "isowork".

According to Burda, Hamermesh and Weil (2013), social gender norms are what allow for the existence of this "iso-work", since such norms serve as a coordinating device between the total work of both men and women, allowing equal opportunities between the sexes in terms of the distribution of time. Social standards exist, and are shared by others and by members of the general community (Elster, 1989). These social standards assume that individuals experience social pressure to conform to a common standard for the allocation of time. See, for example, Gimenez-Nadal et al., 2012, and Gimenez-Nadal and Sevilla, 2014, for the case of Spain, and Burda et al., (2008) for Italy. These authors show how gender social norms encourage an inegalitarian distribution of time between men and women in terms of total work, to the detriment of women, so that these countries are shifted away from "iso-work". 


\section{The use of time data}

\subsection{Description of data and variables}

Our aim is to compare four Latin American countries, with respect to total work (paid work outside the home, and unpaid work within) and the distribution of time. Time use surveys are a method of compiling timely and accurate data on the division of labour in the family context, allowing us to consider the interdependence of both paid and unpaid work.

As indicated by Stuart (2014), although information relating to unpaid work is widely available from a variety of surveys (of income and expenses, of homes and living conditions), time-use surveys are considered the primary statistical tools. Gimenez and Sevilla (2012) show that time-use surveys are the preferred method for gathering information as to the time spent on paid work, unpaid work, and leisure time. (See Aguiar et al., 2008, Krueger, 2007, and Hurst, 2007, who all use data from time use surveys).

The difficulty of obtaining this type of data for Latin American countries, differences in the years of conducting these surveys, and little comparability in terms of the number of questions related to the use of time, have limited our study to four countries: Mexico (2009), Peru (2010), Colombia (2012) and Ecuador (2012). ${ }^{1}$ We can state that, in the case of these countries, these are the first independent time-use surveys, since data was only previously available through other types of survey, such as integrated household surveys. ${ }^{2}$

The population studied are all members of households surveyed after age 12 for Mexico, Peru, and Ecuador, and from age 10 for Colombia. The first three surveys take as reference period the previous week, while for that for Colombia takes as reference period the previous day. Lists of activities based on the following international classifications are used in the data collection: Peru (ICATUS, classification international activities of use of time $)^{3}$; Mexico (CMAUT, classification of the time use) ${ }^{4}$; Ecuador and Colombia (CAUTAL, classification of activities of the use of time for Latin America and the Caribbean) ${ }^{5}$.

\footnotetext{
${ }^{1}$ Both the databases and methodologies for the surveys of the use of time have been obtained through information published by the relevant institutes of statistics in each country. The information obtained for Mexico is from INEGI (National Institute of statistics and geography); for Peru, from INEI (Instituto Nacional de Estadística e Informática); for Colombia from DANE (National Administrative Department of statistics); and for Ecuador from INEC (National Institute of statistics and censuses).

${ }^{2}$ For an overview of the more detailed surveys of time use in Latin-American countries, see Aguirre and Ferrari (2013)

${ }^{3}$ ICATUS is a pilot project for the international classification of activities for time-use statistics, developed during the 1990s. The first material was prepared in 1997. The latest revision was in 2003.

${ }^{4}$ The CMAUT comprises the adaptation of ICATUS to Mexico.

5 CAUTAL is created to meet national requirements and regional mandates, comparable with ICATUS and EUROSTAT. CAUTAL is comparable with ICATUS and CMAUT, since the scheme of ICATUS is the benchmark for CAUTAL.
} 
The structure of ICATUS (Peru) comprises 15 main divisions: work for corporates, quasicompanies, non-profits, and public administration institutions; Work in households (Primary production activities); Work in households (Non-primary production activities);Work in households (Construction activities): work in households (Provision of paid services); Domestic services, unpaid; Unpaid provision of support and care to members of the household; Provision of unpaid services to the community and help to other homes; Study activities; Social life and participation in community activities; Attendance at cultural events, trainings and sports; Hobbies, games and other pastimes; Sports, fitness, and outdoor activities; Use of mass media; and personal care.

CMAUT (Mexico) comprises 11 divisions: structured sectors and households, domestic work unpaid, unpaid services of care and support to members of the household, nonremunerated support services to other homes and the community, study activities, social life with family, friends, other people, and the community, attendance at cultural events, training, sports and competitive, participation in games and hobbies, sports and physical exercise; use of mass media; activities and personal care.

CAUTAL (Ecuador and Colombia) comprises 9 divisions: paid work; activities related to paid work; household chores unpaid; care unpaid of household members; unpaid work for others homes, community and unpaid voluntary work; learning and study; coexistence, culture, hobbies and sport; use of means of communication; and personal care.

For purposes of comparison with prior studies of time use (Aguiar and Hurst, 2007; Giménez-Nadal and Sevilla, 2014), we restrict our sample to individuals between 21 and 65 years of age, who are not students or retirees, ${ }^{6}$ which gives us 28,492 observations for Mexico, 7,243 for Peru, 76,621 for Colombia and 23,345 observations for Ecuador. ${ }^{7}$ We utilise the demographic weights proposed by Katz and Murphy (1992) to ensure a constant of types of individual and days of the week. These demographic weights (see Appendix A) have been used in other time use studies (Aguiar and Hurtz, 2007, 2009; and Gimenez-Nadal and Sevilla, 2012, 2014).

The calculation of time is of weekly hours. The category of total work includes paid and unpaid work, with the latter divided into the categories of general housework and childcare. It is important to make this distinction, since, as pointed out by Sevilla et al.,

\footnotetext{
${ }^{6}$ In the survey of time use for Peru, we have no data on whether individuals are retirees, but we do know that the legal retirement age is 65 , so our limit is valid.

${ }^{7}$ In the case of Ecuador, we consider only those surveys that have been filled out in their entirety by each Member of the household, since parts of the survey could be filled by another Member of the household as the spouse.
} 
(2010) and Gimenez-Nadal and Molina (2013), those women who have a better position in the labour market, rather than reduce their time dedicated to the care of children in the home, increase it. On the other hand, Kahneman, et al., (2004); Kahneman and Krueger (2006); Krueger (2007); and Guryan et al., (2008) all show that the time parents spend on children is an enjoyable activity, so we consider it necessary to separate these activities.

For comparison purposes, we use the definition of categories of time use of Aguiar and Hurst (2007), who consider separate categories for paid work, domestic work, and childcare. (See Appendix B, Tables B1 to B4 for an overview of such activities in the four countries.)

Paid work includes all the time spent working in the paid sector, including main job, a second job where applicable, and overtime, including paid work at home and travel allowances, etc.

Domestic work includes any time spent in the preparation of meals, cleaning, laundry, ironing, dusting, vacuuming, maintenance (including painting and decorating), time spent on the procurement of goods and services (that is, making purchase of groceries, shopping for items for the home), along with time spent on other productive activities at home, such as outdoor cleaning and vehicle repair.

Childcare includes all time spent on childcare as main activity, such as food preparation for babies and children, washing and bathing, changing diapers, putting children and babies to sleep, Babysitting, medical care, reading to or playing with babies and children, helping with homework, and supervisory duties.

\subsection{Trends in total work}

We analyze trends in the time devoted to work, by both men and women, in Mexico, Peru, Colombia and Ecuador. Table 1 presents the work categories, male and female time allocation, and gender differentials. It is clear that these four countries show statistically significant gender differences in favour of men in paid work, while gender differences are statistically significant in favour of women in housework and childcare. The fact that men spend more time in paid work, and women more time in housework and childcare does not vary across countries (Aguiar and Hurst, 2007; Sevilla et al., 2010; Gimenez-Nadal and Sevilla, 2012; Gimenez-Nadal and Sevilla, 2014). 
(Table 1)

Despite the statistically significant differences across these four countries, it is clear that there are different trends towards a more equal sharing of the total work between men and women ("iso-work"). Ecuador presents a bias of 7.34 hours per week against women, and Mexico presents 3.70 hours per week of the same factor. These values are greater than in Peru and Colombia, with the former showing a bias of 1.66 hours per week against women, and the latter showing a bias of 0.46 hours per week of bias against men.

The social norms in each country can, in large part, explain these variations, and gender norms are increasingly used in economic interpretations and models (Fernandez, 2010), interpretations of the division of labour (Brines 1994; Coltrane, 2000; Alvarez and Miles, 2003; Sevilla et al, 2010) and the division of total work (Gimenez-Nadal and Sevilla, 2014).

\section{Social norms}

Social norms are standards that must be shared and fulfilled by members of a community (Elster, 1989). Investigations such as those of Fernandez et al., (2006) and Giuliano (2007), have provided an understanding, in the US case, of how social norms influence the behavior of immigrants. Sevilla (2010) shows that more egalitarian social standards can reduce the discrimination that confronts men participating in activities traditionally considered female; for instance, men help more with household chores and childcare in more egalitarian societies, which can explain how the total workload can be higher for men in certain countries.

To analyze how social norms (culture) influence the distribution of total work in the countries studied, we construct an index to capture which countries are more egalitarian and which are less. To this end, we use the data from the world values survey (WVS), a compilation of national surveys with information on norms and values, such as tolerance of minorities, support for democracy, the role of religion, and support for gender equality. The survey has six waves, the most recent of which covers the years 2010-2014, which corresponds to our surveys of time use.

As in the time-use surveys, we consider individuals between 21 and 65 years of age, who are not students or retired, matching the regions of countries with respect to time use. This indication is particularly relevant in the case of Colombia, as its survey of time use does not contain information on one of its regions, and its survey of values does not provide data on 
another region. Thus, for our study, we consider the regions of Sierra, Costa, and Amazon for Ecuador, Center, Center-West, North, South, and South-East for Mexico, Sierra, Selva, Metropolitan Lima, and the rest of the coast for Peru, and Atlantic, Central, Eastern, Pacific, and Bogotá for Colombia.

The questions that allow us to build the index are designed to elicit individual opinions on gender equality, thus: (1) When a mother works for pay, the children suffer (2) On the whole, men make better political leaders than women do (3) A university education is more important for a boy than for a girl (4) On the whole men make better business executives than women (5) Being a housewife is just as fulfilling as working for pay. The possible responses are on a 4-point scale, thus: 1: agree strongly, 2: agree, 3: disagree 4: disagree strongly. Higher valuations would indicate that respondents in a given country are more egalitarian.

Following the work of Alesina and Giuliano (2007) and Sevilla (2010), and using the Principal Component Analysis (PCA) technique, we extract the first principal component of each of five questions of all individual responses. Thus, a weight is assigned to each question allowing us to obtain an egalitarian index. ${ }^{8}$ The weights assigned to each question are 0.24 to question (1), 0.54 to question (2), 0.54 to question (3), 0.56 to question (4), and 0.20 to question (5). Column 1 of Table 2 shows the results of the index. Ecuador (2.82) and Mexico (2.86) have the lower weightings, indicating that they are less supportive of gender equality, compared with Peru (2.97) and Colombia (2.95). (As in Table 1, countries that show major gender differences in the distribution of total work (Ecuador and Mexico), are also less egalitarian.) Columns 2 to 6 of Table 2 show percentages of responses to our five questions in support of gender equality; the higher the percentages, the more egalitarian the country.

(Table 2)

\section{Descriptive results}

\subsection{Results by demographic groups}

We consider three levels of education: primary (less than a high school degree), secondary (high school degree), and University (more than a high school degree), as well as the

\footnotetext{
${ }^{8}$ Principal Components Analysis (PCA) is a statistical technique that allows us to transform a number of variables that may be correlated to a number of variables that are not correlated, so-called major components that would be associated with the original variables by an orthogonal transformation.
} 
presence, or not, of children in the home. ${ }^{9}$ Table 3.1 shows results from respondents with no children (and therefore no childcare component) and Table 3.2 shows results from respondents with children. We also show the time spent on various activities, gender differences, and the p-values of the difference in accordance with the level of education of men and women. We see clear differences between the two tables. It can be seen that the presence of children in the home is related to an increase in gender differences in the total work, biased against the woman. Also worthy of note is the fact that women with university education in less egalitarian countries (Ecuador and Mexico) spend more time in the total work than men with the same level of training, with or without the presence of children in the home.

(Table 3.1)

(Table 3.2)

Analyzing Table 3.1 (without children) by primary education, we observe that, on average in the four countries, men spend 45.97 hours in paid work per week and 12.68 hours unpaid work (housework), for total work of 58.65 hours, while women spend 20.02 hours in paid work per week and 37.24 hours of unpaid work (housework), for total work of 57.26 hours. Ecuador and Peru show small gender differences against women, 0.73 and 0.46 weekly hours, respectively, while Mexico and Colombia show gender gaps of gender against men of 2.36 and 4.44 hours per week, respectively.

In Table 3.2, for the same level of education, but now with children, men spend 49.59 hours in paid work per week and 11.73 hours in unpaid work (9.76 hours of chores and 1.97 hours in childcare), for total work of 61.32 hours, while women with primary educational level spend 19.09 paid work hours and 45.87 hours unpaid work (39.30 hours of chores and 6.57 hours of childcare) for total work of 64.96 hours. Thus, women have 3.64 more hours of total work than men. Country differences are more marked in less egalitarian countries: Ecuador and Mexico with 8.69 and 4.42 hours per week, respectively, while Peru shows a smaller gap of 2.62 hours weekly, and Colombia again shows men with the greater burden, 1.19 hours per week more than women. Giménez-Nadal and Sevilla (2012) argue that the presence of children changes the distribution of time between men and women. We can

\footnotetext{
${ }^{9} 75 \%$ of Ecuadorian households, $69 \%$ of Mexican households, 75 per cent of Peruvian households, and 65 per cent of Colombian households have children present (see Table A1).
} 
confirm this argument since, as Tables 3.1 and 3.2 show, time distributions change when children are present in the home.

For those with secondary education, with no children, we observe that men devote 48.65 hours per week to paid work and 11.28 hours to unpaid work, for total work of 59.93 hours. Women, on average, spend 28.90 hours per week on paid work and 31.10 hours on unpaid housework, for total work of 60.00 hours per week. The average of our four countries shows an almost imperceptible gender gap of 0.06 hours per week. When we look at individual countries, Ecuador and Peru show small gender gaps against women of 0.98 and 0.12 hours per week, respectively, while the gap is reversed in Mexico and Colombia, showing gaps against men of 0.05 and 0.79 hours per week, respectively.

For those with secondary education, and with children, the picture is slightly different. Men spend 52.03 hours per week on paid work and 11.95 hours on unpaid work (9.30 hours of chores and 2.65 hours of childcare), for total work of 63.98 hours. Women spend 24.61 hours on paid work and 42.63 hours of unpaid work (34.43 hours of chores and 8.21 hours of childcare) for total work of 67.25 hours. This produces a gender gap against women of 3.27 hours per week, on average. By country, the differences are more marked. In Ecuador and Mexico, the gender gap is 6.86 and 4.77 hours, respectively, while Peru and Colombia have smaller gaps of 0.05 and 1.42 hours, respectively. In all four countries, these gaps are against women.

Important changes to consider in the transition from the primary level of education to the secondary is that both men and women increase their participation in the labour market (mainly women with no children), presumably because a higher education allows greater access to the labour market. This, in turn, increases the opportunity cost of time (Becker, 1965). As can be seen, the women exchange more hours of paid work for fewer hours of chores - a result that is more pronounced for women with no children. Women who have children at home, despite decreasing their time dedicated to housework, increase their time spent in the care of their children (1.63 hours per week on average), which is accounted for by Sevilla et al., (2010), through the argument that women specialize in childcare, regardless of their capacity for negotiation or relative productivity.

For those with a University-level education, with no children, a somewhat different pattern emerges. On average, men in this group spend 45.83 hours per week in paid work and 11.57 hours in unpaid housework, for total work of 57.40 hours per week. Women in the same 
group spend 35.05 hours in paid work and 24.64 hours in unpaid housework, for total work of 59.69 hours. The average gender gap is, then, 2.28 hours, against women. Focusing on the countries, Ecuador and Mexico present significant bias against women, of 6.02 and 2.03 hours per week, respectively, while in Peru and Colombia the gender gaps are much smaller, at 0.49 and 0.59 hours per week, respectively.

For those with a University-level education, and with children, men, on average, spend 48.95 hours per week in paid work and 13.28 hours in unpaid work (10.22 hours of chores and 3.06 hours of childcare), for total work of 62.22 hours. Women spend 31.19 hours in paid work and 37.28 hours in unpaid work (29.49 hours of chores and 7.79 hours of childcare) for total work of 68.47 hours, which produces a gender gap against women of 6.25 hours per week. By country, we find that the differences in the distribution of total work are much more marked in Ecuador and Mexico, with 13.05 and 8.00 hours per week, respectively, while in Peru and Colombia, the differences are much less with 0.96 and 3.00 hours per week, respectively.

In the transition from secondary education to University, we observe different preferences between men and women. University-educated men spend less time in total work than secondary-educated men, three hours less per week (with or no children in the home). University-educated women, on the other hand, spend more time on paid work compared to women with secondary education, with an average of more than six hours (with or no children in the home). Men at this level decrease their hours of work, but do not present major changes in terms of the time spent on unpaid work (in the case of Mexico, there are decreases in the time spent on unpaid work. ${ }^{10}$ Women, on the other hand, by increasing their time in paid work, reduce the time spent on housework. When children are present, women with university education spend almost the same amount of time in childcare as women with secondary education, but reduce the hours spent in housework.

The presence of children in the home appears to accentuate gender differences in total work, mainly in the cases of Ecuador and Mexico and should, as indicated by Gimenez-Nadal and Sevilla (2014) and Sevilla et al., (2010), increase the gender gap in total work in less egalitarian countries. Traditional norms of femininity dominate standards of masculinity in

\footnotetext{
${ }^{10}$ In another context, Giménez-Nadal and Molina (2014), for the Spanish case, show that men who spend less time at work due to unemployment, do not spend any more time helping their spouse with domestic chores and child care, despite having more time available.
} 
these two countries. In Ecuador and Mexico, regardless of the presence of children, at the University level of education we find gender gaps against women, indicating that traditional social standards, such as those expressed by Hochschild and Machung (1989) and Arkelof and Kranton (2000), are still prevalent, as in the notion that "If a woman earns more than her husband, she must commit herself to do more domestic tasks, so that the man does not lose his identity".

\subsection{Results by Country}

In addition to considering the importance of social standards in the distribution of the total work between genders, and how this distribution can vary depending on level of training and the presence of children in the home, it is necessary to also consider the effects of the factors specific to each country. These factors could lead to large or small gender differentials in total work, and could bias the results if overlooked. Thus, we consider variables of income, of the labour market, and of the marriage market.

In Table 4, we consider, in column 1, GDP per capita of each country. Burda., et al (2013) show that economic development is associated with gender neutrality in the total work "isowork", and is positively correlated with higher levels of per capita GDP. Colombia, in general terms (see Table 1), is the most egalitarian country in terms of the distribution of total work, and it is also the country with the greater PIB, which confirms this hypothesis. Column 2 of Table 4 shows the female unemployment rate of the four countries. Fernandez (2007) argues that countries with more traditional norms regarding the role of women tend to have a lower labor force participation rate for women. We note that, in comparison to Ecuador (our country with the least gender equality), Mexico and Peru have a lower rate of female unemployment. In the case of Colombia, which has a higher rate of female unemployment, and is one of the two most egalitarian countries (in terms of the overall division of labour), there is a smaller share of women in paid work in comparison with other countries. ${ }^{11}$

\section{(Table 4)}

Column 3 of Table 4 shows the proportion of women for every 100 men in all four countries (sex ratio). This indicator is mainly discussed in the literature of the marriage

\footnotetext{
${ }^{11}$ The male unemployment rate is also higher in Colombia, compared to the other three countries. According to the World Bank for the year 2012, the male unemployment rate for Ecuador was 3.1\%, for Mexico, 4.9\%, for Peru, 3.3\%, and for Columbia, $8.0 \%$.
} 
market (see Grossbard and Amuedo-Dorantes, 2007, and Grossbard and Sechtman 1984). Gimenez Nadal et al (2012) argue that a lower proportion of women would make women more valued, which would imply a greater equity in the distribution of total work. We can see that this is true in the case of Peru, since it is the country with the lowest proportion of women, which may be one reason why we do not see major gender differentials in the distribution of total work (see Tables 1, 3.1 and 3.2). Column 4 of Table 4 shows fertility rates. Alessina and Giuliano (2007) relate higher fertility rates to traditional families, in which women are mainly devoted to household tasks, while men spend most of their time in the labour market. This, in turn, leads to women having a lower level of education. We note that Ecuador has the highest fertility rate of our four countries, which may be why the country is characterised by traditional behaviors that are detrimental to women in their allocation of time.

Finally, column 5 of Table 4 shows gross rates of divorce among countries. Sevilla (2010) shows that more egalitarian countries as Norway and Sweden have a higher proportion of individuals in couples, in comparison to less egalitarian countries, such as Japan and Spain. We note that both Ecuador and Mexico have higher rates of divorce than Peru and Colombia, coinciding with our rankings of which countries are more egalitarian and which not. The fact of being in a couple, or not, could also be an influential factor in total work.

\section{Econometric analysis and empirical findings}

We estimate the regressions of the time dedicated to total work through Ordinary Least Squares (OLS). Gershuny (2012) argues that OLS models can deliver accurate estimates of average activity times for samples and subgroups. Frazis and Stewart (2012) also prefer these models for the analysis of time-allocation decisions, while Foster and Kalenkoski (2013) discussing the analysis of childcare time, compare OLS and Tobit models, finding that the qualitative conclusions of the two models are similar.

First, we estimate through OLS:

$$
T_{i k}=\alpha+\beta_{1} \text { Woman }_{i k}+\beta_{2} x_{i k}+\beta_{3} Z_{k}+\beta_{4} I_{k}+\varepsilon_{i k}
$$

where $T_{i k}$ is the time spent in total work by the individual, Woman $_{i k}$ takes value 1 if the respondent is female, and o otherwise, $x_{i k}$ is a vector of variables that includes dummies for primary education, university education (secondary education as reference), the presence of children under age 18 in the home, and the number of members of the household, the age and 
age squared of the respondent, $Z_{k}$ represents country-specific factors, $I_{k}$ represents the variables of the countries (with Ecuador as reference), and y $\varepsilon_{i k}$ is the error term.

The dummy variable Woman $_{i k}$ is included to measure gender differences among countries. $\beta_{1}>0$ indicates that women spend more time in total work than do men.

Column 1 of Table 5 shows the results of the estimation of equation 1, without considering country-specific factors, with male being the reference category. We can see that $\beta_{1}$ is positive and statistically significant $(\mathrm{p}<0.01)$, indicating that there is a gender gap in total work that favours women. Columns 2 to 6 of Table 5 consider separately the country factors, as explained in Table 4 . While all variables provide significant values $(\mathrm{p}<0.01)$ against women, gender gaps are not reduced, remaining at $\beta_{1}>0$. Column 7 includes the countryspecific factors and, although 5 variables remain significant $(\mathrm{p}<0.01)$, no changes occur, and $\beta_{1}>0$, that is, the gender gaps remain.

\section{(Table 5)}

To measure the effect of social standards, we include the variable $E I_{k}$ in Equation 1 . The social norms of each country are represented by the egalitarian index $E I_{k}$, whose higher values represent more egalitarian social norms, which leads to:

$$
T_{i k}=\alpha+\beta_{1} \text { Woman }_{i k}+\beta_{2} x_{i k}+\beta_{3} Z_{k}+\beta_{4} I_{k}+\beta_{5} E I_{k}+\varepsilon_{i k}
$$

In Table 6, column 1 (without country factors) and column 2 (with country factors) both show positive and significant values $(\mathrm{p}<0.01)$ of the variable Woman $_{i k}$, indicating gender gaps against women, $\beta_{1}>0$. In column 3 , the gaps disappear and this variable is no longer significant. The results in column 3 confirm that the egalitarian index is positive and significant ( $<<0.01$ ). This coefficient, multiplied by the difference between the value of the most egalitarian country and the least (see Table 2 data on Ecuador and Peru) gives us a result that could reduce the gender gap against women by up to 1.82 hours per week.

\section{(Table 6)}

We now analyze how social norms influence the presence, or not, of children in the home, for the three levels of education. Column 1 of Table 7 (primary) shows that the variable Woman $_{i k}$ is significant $(\mathrm{p}<0.01)$ and negative, with $\beta_{1}<0$, indicating a gender gap against men. Some factors that, in part, allow us to explain this circumstance can be seen in Table 3.1. Gender roles are more defined than in the other two levels of education, in the sense that men spend more hours per week in paid work to unpaid work, while women spend 
more time on unpaid work compared to men and, in turn, fewer hours in paid work compared to women with higher levels of education. Column 2 of Table 7 shows that, when we take into account the more egalitarian social norms, the gender gap against men increases, since the variable Woman $_{i k}$ continues to be negative and significant ( $\left.<<0.01\right)$, but this value is higher than in column 1. It is important to note that, at the primary level of education, only 28\% approximately of households have no children present in the home (see Appendix A).

\section{(Table 7)}

Column 3 of Table 7 shows that the variable Woman $_{i k}$ is not significant. Men and women increase their hours of paid work, and decrease their hours of unpaid work, with an equitable distribution of total work. Column 4 (secondary education, with egalitarian index), by including social norms, moves the gender gap against men, since the female variable is negative and significant ( $<<0.01)$. Men take on a greater overall workload and, as for the primary level of education, only $28 \%$ of households have no children present.

Column 5 of Table 7 (university level) shows that the variable Woman $_{i k}$ is positive and significant ( $\mathrm{p}<0.01)$, and at this level of education we find a gender gap against women, as shown by $\beta_{1}>0$. Column 6 (university education, with the egalitarian index) shows that the variable Woman $_{i k}$ is no longer significant and egalitarian index is positive and significant $(\mathrm{p}<0.01)$, that is to say, the gender gap against women disappears. As social norms become more egalitarian, men increase their hours of total work, and at this level of education, on average, $41.20 \%$ of households do not have children present.

We now consider households where children are present. As seen in Table 3.2 (compared to Table 3.1), men at all three education levels spend more hours per week in paid work, while women decrease their time spent in paid work, bearing, as they do, a larger burden in childcare. This is clear when we look at Table 8.

Column 1 of Table 8 (primary education) shows a gender gap against women, since the variable Woman $_{i k}$ is positive and significant ( $>$ > 0.01). Column 2 of Table 8 shows that, for the egalitarian index to be meaningful $(\mathrm{p}<0.01)$ it should eliminate the gender bias against women. As the country is more egalitarian, the men devote more hours to total work, thus reducing gender disparities. Column 3 (secondary education) shows that the variable Woman $_{i k}$ is negative and significant $(\mathrm{p}<0.01)$, and we find a gender gap against women because $\beta_{1}>0$. Column 4 (secondary with egalitarian index) shows that, for the index to be meaningful, ( $<<0.5$ ), it should eliminate the gender gap against women, but this is not the 
case, since the variable Woman $_{i k}$ remains significant and positive, at $\beta_{1}>0$, but with a smaller value than in column 3. Egalitarian social norms help to reduce, but to a lesser extent, the gender gap against women. Column 5 (university) shows that the variable Woman $_{i k}$ is positive and significant ( $\mathrm{p}<0.01$ ), and the gender gap is against women, $\beta_{1}>0$, and larger than in the other levels of education (columns 1 and 3). Column 6 (university with egalitarian index) shows that the variable women decreases somewhat, and is negative and significant, as $\beta_{1}>0$, showing that the gender gap against women remains important. Unlike in the other columns, the egalitarian index ceases to be meaningful, so, for this level of education, and considering the presence of children in the home, more egalitarian social norms do not help to reduce the gender bias against women. On average, more than $71 \%$ of households with primary and secondary education show the presence of children at home, while households with university education exhibit a lower percentage, with only $58.8 \%$ having children present.

\section{(Table 8)}

The results show that more egalitarian social norms have effects in favour of women, when there are children in the household. These social norms lead to men spending more time in total work, compared to women, and gender differences are diminished, or even disappear, as in the case of the University level of education. When children are present, we see that egalitarian social norms lose their influence as the level of education improves, which may be due to the limitations present in the labour market for mothers, when inadequate services are offered for childcare.

Other research in Latin America shows the difficulties encountered by mothers. Mateo Diaz and Rodriguez-Chamussy (2013) find major obstacles to the labour-market participation of mothers of young children. In terms of wage differentials by gender, although they are still the norm in Latin America (Gallardo and Ñopo 2009), such discrepancies are greater for mothers of young children (Piras and Ripani, 2005; Pages and Piras, 2010). The latter authors show that women with young children, in their desire to reconcile their responsibilities, take on part-time work which, combined with daily household tasks, result in long hours of total work. Araujo et al., (2013), studying childcare services, find that there are still many difficulties and problems in terms of education and childcare in Latin America, including lack of proper education and training, access to facilities, and lack of control and regulation of private sector services. It should be noted, in addition, that the provision of such services is 
generally only on a part-time basis, as shown by Berlinski et al (2011) for the case of Argentina.

The persistence of gender differentials, even for highly-educated women, may be due to the fact that, having greater human capital, such women must invest most of their time in paid work (compared to the other two levels of training), since a larger portion of the household total income may depend on them. Mateo Díaz and Rodriguez-Chamussy (2013) show that, for the higher income quintiles of income (for our four countries of studies), women contribute, on average, $43.12 \%$ of total household income. Difficulties in the labour market, inadequate provision of childcare services, and the necessity to provide a significant portion of household income, are all obstacles in the way of gender equity, that also impose limits on the effects of egalitarian social norms.

\section{Conclusions}

In this study, we have analyzed the time-allocation decisions, by men and women in four Latin-American countries, using time use surveys of Mexico (2009), Peru (2010), Colombia (2012) and Ecuador (2012). The results indicate that Ecuador and Mexico have greater gender differences in the distribution of total work. To explain these gender differentials, we examine the influence of the social norms of each country, by constructing an index from data contained in the last wave (2010 to 2014) of the World Values Survey WVS). This index allows us to determine that the more egalitarian of these four countries, Peru and Colombia, are those that display only minor gender differences in total work. At the same time, our econometric results confirm that gender differentials are beginning to disappear as countries become more egalitarian.

From an overview of the four countries, we divide our sample according to three levels of education (primary, secondary, and University), and as to whether, or not, there are children present in the household. Our econometric results show that more egalitarian social norms positively influence women's total work, provided that there are no children present in the home. When children are present, the egalitarian social norms lose their influence as the level of education rises. This could be due to the prevailing difficulties in the labour market for mothers with young children, and the lack of adequate child-care services available for working mothers, a problem that is more, or less, acute, depending on the country. 
Our recommendations in terms of public policy are that Governments should encourage companies to hire more women who have children, by, for example, giving tax credits for such hires. Additionally, while there has been progress in offering more - and better - childcare services, Governments can, and should, do more (Araujo et al, 2013).

\section{References}

Alvarez, B. and Miles, D. (2003) Gender-effect in housework allocation: evidence from Spanish two-earner couples, Journal of Population Economics, 16, 227-42.

Aguiar, M. and Hurst, E. (2007) Measuring trends in leisure: the allocation of time over five decades, Quarterly Journal of Economics, 115, 969-1006.

Aguiar, M. and Hurst, E. (2009) A summary of trends in American time allocation: 19652005, Social Indicators Research, 93, 57-64.

Aguirre, R., and Ferrari, F. (2013). Surveys on time use and unpaid work in Latin America and the Caribbean: Experience to date and challenges for the future. United Nations (ECLAC).

Akerlof, George A. and Rachel E. Kranton. (2000). Economics and Identity, Quarterly Journal of Economics , 115 (3): 715-53.

Alesina A, and Giuliano P (2007) The power of the family. Working Paper 13051. National Bureau of Economic Research

Araujo, M. C., Lopez Boo, f., and Puyana, J. M. (2013).Overview of early childhood development services in Latin America and the Caribbean. Inter-American Development Bank.

Baxter, J. (2002) Patterns of change and stability in the gender division of household labour in Australia, 1996-1997 Journal of Sociology, 38, 399-424.

Becker GS (1965) A theory of the allocation of time. ECON J 75:493-517

Berlinski S, Galiani S, and McEwan P (2011) and Preschool and nursery school Labor Market Outcomes: Evidence from a Regression Discontinuity Design. Economic Development and Cultural Change, 59 (2): 313-344.

Bianchi, S. M. (2000) Maternal employment and time with children: dramatic change or surprising continuity? Demography, 37, 401-414. 
Bianchi, Suzanne M., John P. Robinson, and Melissa A. Milkie. (2006) Changing Rhythms of American Family Life. New York: Russell Sage Foundation.

Bittman, M. (1999) Now that the future has arrived: a retrospective of Gershuny's theory of social innovation, Social Policy Research Centre, Discussion Paper, no. 110, University of New South Wales, Kensington.

Burda M, Hamermesh and D Weil P (2007) Total work, gender and social norms. NBER Working Paper No. 13000

Burda, M., Hamermesh, D. and Weil, P. (2008) The distribution of total work in the US and EU, in Working Hours and Job Sharing in the EU and USA: Are Americans Crazy? AreEuropeans Lazy?, Boeri, T., Burda, M. and Kramarz, f. (Eds), Oxford University Press, Oxford.

Burda, M., Hamermesh, D. and Weil, P. (2013) Total work and gender: facts and possible explanations, Journal of Population Economics, 26, 239-61.

Brines, J. (1994) Economic dependency, gender, and the division of labor at home, American Journal of Sociology, 100, 652-88.

Canelas, C., and Salazar, S. (2014). Gender and ethnic inequalities in LAC countries. IZA Journal of work \& Development, 3(1), 18.

Coltrane, S. (2000) Research on household work: modeling and measuring the social embeddedness of routine familywork, Journal of Marriage and the Family, 62, 1208-33.

Duryea, S., A.C. Edwards and M. Ureta. (2004). "Women in the LAC work Market: The Remarkable 1990s". In: Piras, Claudia (ed.). Women at Work: Challenges for Latin America. Washington, D.C.: IDB.

Elster, J. (1989). Social norms and economic theory. The Journal of Economic Perspectives, 99-117.

Fernandez R , Fogli , Olivetti C (2006) Fertility: the role of culture and family experience, Journal of European Economic Association, 4 (3): 552-561

Fernandez R. (2007) Women, work and culture Journal of European Economic Association, 5 (2): 305-333

Fernandez R. (2010) Does culture matter? In: J. Benhabib, Bisin A, Jackson M (eds) Handbook of social economics, vol 1a. Elsevier, Amsterdam, pp 481-510 
Fleming Robing and Spellerberg Anne, (1999), Using Time Use Data: A History of TimeUse Surveys and use of Time Use Data. New Zealand: Statistics New Zealand

Folbre, N. (2006). Measuring Care: Gender, Empowerment, and the Care Economy. Journal of Human Development, 7 (2), 183-200.

Foster, G. and Kalenkoski, C. (2013) and Tobit or OLS? An empirical evaluation under different diary window lengths, Applied Economics, 45, 2994-3010.

Frazis, H. Stewart, J. (2012) and How to think about time - use data: what inferences can we make about long-and shortrun time use from time use diaries?, Annals of Economics and Statistics, 105/106, 231-46.

Gallardo, l., \& Nopo, H. (2009). Ethnic and gender wage gaps in Ecuador (No. 679). Working paper. Inter-American Development Bank, Research Department.

Garcia, I., Molina, J.A. and Montuenga, V. (2010). Intra-family distribution of paid-work time. Applied Economics, 42, 589-601.

Garcia, I., Molina, J.A. and Montuenga, V. (2011). Gender differences in childcare: time allocation in five European countries. Feminist Economics, 17 (1), 119-150.

Gershuny, Jonathan. (2000) Changing Times: Work and Leisure in post-industrial Society. Oxford: Oxford University Press.

Gimenez-Nadal, J. I. Molina, J. A. (2013) and Parents'education as a determinant of educational childcare time, Journal of Population Economics, 26, 719-49.

Giménez-Nadal, J. I. Molina, J. A. (2014) and Regional unemployment, gender, and time allocation of the unemployed, Review of the Economics of the Household, 12 (1): 105-127

Gimenez-Nadal, J. I., Molina, J. A., \& Sevilla-Sanz, a. (2012).Social norms, partnerships and children. Review of the Economics of the Household, 10(2), 215-236.

Gimenez-Nadal, J. I. Sevilla, A. (2012) and Trends in time allocation: a cross country analysis, European Economic Review, 56, 1338-59.

Gimenez-Nadal, J. I., \& Sevilla, A. (2014).Total work time in Spain: evidence from time diary data. Applied Economics, 46(16), 1894-1909.

Giuliano, P (2007) Living arrangements in western Europe: does cultural origin matter? Journal of European Economic Association 5 (5): 927-952 
Grossbard, S., \& Amuedo-Dorantes, C. (2007).Marriage markets and women's labor force participation. Review of the Economics of the Household, 5, 249-278.

Grossbard-Sechtman, A. (1984). A theory of the allocation of time in markets for labour and marriage. Economic Journal, 94, 863-882.

Guryan, J., Hurst, E and Kearney, M. (2008) Parental education and paretal time with children. Journal of Economic Perspectives, 22, 23-46

Hochschild, Arlie Russell and Anne Machung. (1989) The Second Shift: Working Parents and the Revolution at Home. New York: Viking.

Kahneman, D and Krueger, A. B. (2006) Developments in the measurement of subjective well-being, Journal of Economic Perspectives, 20, 3-24.

Kahneman, D., Krueger, A. B.,and Schkade, D. (2004) a survey method for characterizing daily life experience: the day reconstruction method, Science, 306, 1776-1780.

Katz, l. and Murphy, k. (1992) Changes in relative wages, 1963-1987: supply and demand factors, Quarterly Journal of Economics, 107, 35-78.

Krueger, A. B. (2007) Are we having more fun yet? Categorizing and evaluating changes in time allocation, Brooking Papers on Economic Activity, 2, 193-217.

Mateo Diaz, M., and Rodriguez Chamussy, l. (2013). Childcare and Women's work Participation: Evidence for Latin America and the Caribbean. Inter-American Development Bank.

Molina, J.A. and Montuenga, V. (2009). The motherhood wage penalty in Spain, Journal of Family and Economic Issues, 20, 237-251.

Pages, C., and Piras, C. (2010). The Gender Dividend: Capitalizing on Women's Work. InterAmerican Development Bank.

Piras, C, and Ripani L. (2005). "The Effects of Motherhood on Wages and Labor Force Participation: Evidence from Bolivia, Brazil, Ecuador and Peru." Sustainable Development Department Technical Papers Series. WID-109

Sevilla, A. (2010) Household division of labor and cross-country differences in household formation rates, Journal of Population Economics, 23, 225-49.

Sevilla, A. Giménez-Nadal, J. I. and Fernandez, C. (2010) Gender roles and the division of unpaid work in Spanish households, Feminist Economics, 16, 137-84. 
Stuart, S. (2014). Situation of unpaid work and gender in the Caribbean: The measurement of unpaid work through time - use studies. United Nations (ECLAC). 
Table 1 Time devoted to paid work, unpaid work, childcare and total work, by gender, for Ecuador, Mexico, Peru and Colombia.

\begin{tabular}{|c|c|c|c|c|c|c|}
\hline \multirow[b]{2}{*}{ Hours per week } & \multicolumn{2}{|c|}{ Men } & \multicolumn{2}{|c|}{ Women } & \multirow[b]{2}{*}{ Difference } & \multirow[b]{2}{*}{ P-value } \\
\hline & Mean & $\mathrm{SD}$ & Mean & SD & & \\
\hline \multicolumn{7}{|l|}{ Paid work } \\
\hline Ecuador & 48.57 & $(15.94)$ & 2259 & $(24.50)$ & 25.99 & $(0.000)$ \\
\hline Mexico & 49.68 & $(21.84)$ & 21.49 & $(25.54)$ & 28.19 & $(0.000)$ \\
\hline Peru & 50.93 & (18.67) & 24.72 & (23.66) & 26.21 & $(0.000)$ \\
\hline Colombia & 46.91 & (32.01) & 20.05 & (29.35) & 26.86 & $(0.000)$ \\
\hline \multicolumn{7}{|l|}{ Unpaid work } \\
\hline Ecuador & 9.13 & $(9.88)$ & 37.54 & $(19,13)$ & -28.41 & $(0.000)$ \\
\hline Mexico & 10.76 & (10.61) & 38.91 & (20.04) & -28.15 & $(0.000)$ \\
\hline Peru & 13.35 & $(9.74)$ & 37.69 & (15.91) & -24.34 & $(0.000)$ \\
\hline Colombia & 8.43 & (12.63) & 31.61 & (19.80) & -23.18 & $(0.000)$ \\
\hline \multicolumn{7}{|l|}{ Childcare } \\
\hline Ecuador & 1.51 & $(3.42)$ & 6.43 & $(8.21)$ & -4.92 & $(0.000)$ \\
\hline Mexico & 1.40 & (3.23) & 5.13 & (7.95) & -3.74 & $(0.000)$ \\
\hline Peru & 1.96 & (3.06) & 5.48 & (7.66) & -3.53 & $(0.000)$ \\
\hline Colombia & 1.65 & $(4.51)$ & 4.88 & $(8.60)$ & -3.22 & $(0.000)$ \\
\hline \multicolumn{7}{|l|}{ Total Work } \\
\hline Ecuador & 59.22 & (18.33) & 66.56 & (29.15) & -7.34 & $(0.000)$ \\
\hline Mexico & 61.84 & (23.03) & 65.54 & (27.35) & -3.70 & $(0.000)$ \\
\hline Peru & 66.23 & (17.93) & 67.89 & (19.86) & -1.66 & $(0.002)$ \\
\hline Colombia & 56.99 & (29.97) & 56.53 & (26.89) & 0.46 & $(0.026)$ \\
\hline Observations & \multicolumn{2}{|c|}{62111} & \multicolumn{2}{|c|}{73589} & & \\
\hline
\end{tabular}


Table 2. Egalitarian Index.

\begin{tabular}{lcccccc}
\hline Country & Egalitarian & Attitudes & Attitudes & Attitudes & Attitudes & Attitudes \\
& Index & 1 & 2 & 3 & 4 & 5 \\
\hline Ecuador & 2.82 & 2.18 & 2.91 & 3.03 & 3.02 & 2.25 \\
& $(0.67)$ & $(0.98)$ & $(0.97)$ & $(0.92)$ & $(0.92)$ & $(1.06)$ \\
Mexico & 2.86 & 2.55 & 2.94 & 2.96 & 3.01 & 2.32 \\
& $(0.56)$ & $(0.85)$ & $(0.78)$ & $(0.81)$ & $(0.72)$ & $(0.96)$ \\
Peru & 2.97 & 2.66 & 3.07 & 3.12 & 3.12 & 2.31 \\
& $(0.54)$ & $(0.80)$ & $(0.80)$ & $(0.77)$ & $(0.72)$ & $(0.89)$ \\
Colombia & 2.95 & 2.62 & 2.93 & 3.22 & 3.03 & 2.41 \\
& $(0.52)$ & $(0.87)$ & $(0.82)$ & $(0.71)$ & $(0.80)$ & $(0.89)$ \\
Mean & 2.89 & 2.51 & 2.96 & 3.07 & 3.04 & 2.33 \\
& $(0.58)$ & $(0.89)$ & $(0.84)$ & $(0.81)$ & $(0.81)$ & $(0.96)$ \\
Observations & 4292 & 4292 & 4292 & 4292 & 4292 & 4292 \\
\hline
\end{tabular}

Note: The sample is restricted to individuals between 21 and 65, who are not students and not retired. Higher values indicate more egalitarian social norms. Attitudes of 1 to 5, representing the percentage of individuals who: strongly agree, agree, disagree and strongly disagree with the assertions raised by the following questions: (1) When a mother works for pay, the children suffer (2) On the whole, men make better political leaders than women do (3) A university education is more important for a boy than for a girl (4)On the whole men make better business executives than women (5) Being a housewife is just as fulfilling as working for pay. Standard deviations in parentheses. 
Table 3.1 Differences by gender, considering education levels, in time devoted to paid work, unpaid work and total work for Ecuador, Mexico, Panama, Peru and Colombia, without the presence of minors in the household.

\begin{tabular}{|c|c|c|c|c|c|c|c|c|c|c|c|c|c|c|}
\hline \multirow[b]{3}{*}{ Ecuador } & \multicolumn{4}{|c|}{ Paid work } & \multicolumn{4}{|c|}{ Unpaid work } & \multicolumn{4}{|c|}{ Total Work } & \multicolumn{2}{|c|}{ Observations } \\
\hline & Men & Women & Diff & P-Value & Men & Women & Diff & P-Value & Men & Women & Diff & P-Value & Men & Women \\
\hline & & & & & & & & & & & & & & \\
\hline $\begin{array}{l}\text { Primary } \\
\text { Education }\end{array}$ & $\begin{array}{c}45.86 \\
(17.03)\end{array}$ & $\begin{array}{c}20.97 \\
(23.89)\end{array}$ & 24.89 & $(0.0000)$ & $\begin{array}{c}12.26 \\
(11.37)\end{array}$ & $\begin{array}{c}37.88 \\
(19.53)\end{array}$ & -25.62 & $(0.0000)$ & $\begin{array}{c}58.12 \\
(19.32)\end{array}$ & $\begin{array}{l}58.86 \\
(29.10)\end{array}$ & -0.73 & $(0.3650)$ & 1876 & 1854 \\
\hline $\begin{array}{l}\text { Secondary } \\
\text { Education }\end{array}$ & $\begin{array}{c}48.36 \\
(17.71)\end{array}$ & $\begin{array}{c}27.62 \\
(25.13)\end{array}$ & 20.73 & $(0.0000)$ & $\begin{array}{c}10.77 \\
(10.66)\end{array}$ & $\begin{array}{c}32.49 \\
(19.43)\end{array}$ & -21.71 & $(0.0000)$ & $\begin{array}{l}59.14 \\
(2035)\end{array}$ & $\begin{array}{l}60.12 \\
(26.74)\end{array}$ & -0.98 & $(0.5126)$ & 549 & 443 \\
\hline $\begin{array}{l}\text { University } \\
\text { Education }\end{array}$ & $\begin{array}{c}46.32 \\
(14.71)\end{array}$ & $\begin{array}{c}37,38 \\
(21.00)\end{array}$ & 8.94 & $(0.0000)$ & $\begin{array}{l}11.12 \\
(9.97)\end{array}$ & $\begin{array}{c}26.09 \\
(17.33)\end{array}$ & -14.96 & $(0.0000)$ & $\begin{array}{c}57.45 \\
(17.44)\end{array}$ & $\begin{array}{l}63.47 \\
(23.64)\end{array}$ & -6.02 & $(0.0000)$ & 539 & 492 \\
\hline $\begin{array}{l}\text { Total } \\
\text { Mexico }\end{array}$ & & & & & & & & & & & & & 2964 & 2789 \\
\hline $\begin{array}{l}\text { Primary } \\
\text { Education }\end{array}$ & $\begin{array}{c}45.71 \\
(23.52)\end{array}$ & $\begin{array}{c}17.12 \\
(24.80)\end{array}$ & 28.59 & $(0.0000)$ & $\begin{array}{c}11.89 \\
(1155)\end{array}$ & $\begin{array}{c}38.13 \\
(19.71)\end{array}$ & -26.24 & $(0.0000)$ & $\begin{array}{l}57.60 \\
(24.64)\end{array}$ & $\begin{array}{l}55.25 \\
(27.25)\end{array}$ & 2.36 & $(0.0009)$ & 2612 & 2728 \\
\hline $\begin{array}{l}\text { Secondary } \\
\text { Education }\end{array}$ & $\begin{array}{c}49.95 \\
(21.26)\end{array}$ & $\begin{array}{c}31.94 \\
(26.01)\end{array}$ & 18.01 & $(0.0000)$ & $\begin{array}{c}12.49 \\
(10.80)\end{array}$ & $\begin{array}{c}30.46 \\
(17.61)\end{array}$ & -17.96 & $(0.0000)$ & $\begin{array}{l}62.44 \\
(2255)\end{array}$ & $\begin{array}{c}62.39 \\
(25.78)\end{array}$ & 0.05 & $(0.9707)$ & 577 & 649 \\
\hline $\begin{array}{l}\text { University } \\
\text { Education }\end{array}$ & $\begin{array}{c}48.07 \\
(20.63)\end{array}$ & $\begin{array}{c}35.90 \\
(23.12)\end{array}$ & 12.17 & $(0.0000)$ & $\begin{array}{c}11.96 \\
(10.88)\end{array}$ & $\begin{array}{c}26.16 \\
(17.34)\end{array}$ & -14.20 & $(0.0000)$ & $\begin{array}{c}60.03 \\
(22.27)\end{array}$ & $\begin{array}{l}62.06 \\
(23.50)\end{array}$ & -2.03 & $(0.0434)$ & 1125 & 963 \\
\hline $\begin{array}{l}\text { Total } \\
\text { Peru }\end{array}$ & & & & & & & & & & & & & 4314 & 4340 \\
\hline $\begin{array}{l}\text { Primary } \\
\text { Education }\end{array}$ & $\begin{array}{c}48.64 \\
(19.72)\end{array}$ & $\begin{array}{c}25.13 \\
(24.07)\end{array}$ & 23.52 & $(0.0000)$ & $\begin{array}{c}16.32 \\
(11.02)\end{array}$ & $\begin{array}{c}40.30 \\
(15.84)\end{array}$ & -23.40 & $(0.0000)$ & $\begin{array}{c}64.97 \\
(21.39)\end{array}$ & $\begin{array}{c}65.43 \\
(20.59)\end{array}$ & -0.46 & $(0.7508)$ & 390 & 442 \\
\hline $\begin{array}{l}\text { Secondary } \\
\text { Education }\end{array}$ & $\begin{array}{c}51.83 \\
(19.45)\end{array}$ & $\begin{array}{c}30.18 \\
(26.28)\end{array}$ & 21.65 & $(0.0000)$ & $\begin{array}{l}13.06 \\
(9.23)\end{array}$ & $\begin{array}{c}34.84 \\
(17.35)\end{array}$ & -21.77 & $(0.0000)$ & $\begin{array}{c}64.89 \\
(19.04)\end{array}$ & $\begin{array}{c}65.02 \\
(20.81)\end{array}$ & -0.12 & $(0.9492)$ & 268 & 165 \\
\hline $\begin{array}{l}\text { University } \\
\text { Education }\end{array}$ & $\begin{array}{c}49.22 \\
(21.46)\end{array}$ & $\begin{array}{c}36.62 \\
(2325)\end{array}$ & 12.59 & $(0.0000)$ & $\begin{array}{l}13.39 \\
(8.72)\end{array}$ & $\begin{array}{c}26.58 \\
(15.02)\end{array}$ & -13.18 & $(0.0000)$ & $\begin{array}{c}62.61 \\
(19.90)\end{array}$ & $\begin{array}{c}63.20 \\
(19.49)\end{array}$ & -0.59 & $(0.7371)$ & 278 & 231 \\
\hline $\begin{array}{l}\text { Total } \\
\text { Colombia }\end{array}$ & & & & & & & & & & & & & 936 & 838 \\
\hline $\begin{array}{l}\text { Primary } \\
\text { Education }\end{array}$ & $\begin{array}{c}43.68 \\
(32.04)\end{array}$ & $\begin{array}{c}16.84 \\
(27.78)\end{array}$ & 26.84 & $(0.0000)$ & $\begin{array}{c}10.26 \\
(13.75)\end{array}$ & $\begin{array}{c}32.66 \\
(19.82)\end{array}$ & -2240 & $(0.0000)$ & $\begin{array}{c}53.94 \\
(30.53)\end{array}$ & $\begin{array}{l}49.50 \\
(26.23)\end{array}$ & 4.44 & $(0.0000)$ & 6083 & 6060 \\
\hline $\begin{array}{l}\text { Secondary } \\
\text { Education }\end{array}$ & $\begin{array}{c}44.45 \\
(33.08)\end{array}$ & $\begin{array}{c}25.85 \\
(31.99)\end{array}$ & 18.60 & $(0.0000)$ & $\begin{array}{c}8.79 \\
(12.76)\end{array}$ & $\begin{array}{c}26.60 \\
(20.09)\end{array}$ & -17.80 & $(0.0000)$ & $\begin{array}{c}53.24 \\
(31.09)\end{array}$ & $\begin{array}{c}52.45 \\
(28.35)\end{array}$ & 0.79 & $(0.3196)$ & 3144 & 2569 \\
\hline $\begin{array}{l}\text { University } \\
\text { Education } \\
\text { Total }\end{array}$ & $\begin{array}{c}39.72 \\
(32.53)\end{array}$ & $\begin{array}{c}30.30 \\
(31.82)\end{array}$ & 9.42 & $(0.0000)$ & $\begin{array}{c}9.80 \\
(13.02)\end{array}$ & $\begin{array}{c}19.71 \\
(18.57)\end{array}$ & -9.91 & $(0.0000)$ & $\begin{array}{c}49.52 \\
(30.77)\end{array}$ & $\begin{array}{c}50.01 \\
(29.02)\end{array}$ & -0.49 & $(0.4424)$ & $\begin{array}{r}4138 \\
13365\end{array}$ & $\begin{array}{l}4563 \\
13192\end{array}$ \\
\hline
\end{tabular}

Note: The sample is restricted to individuals between 21 and 65, who are not students and not retired. Paid work, unpaid work, and total work, are measured in hours per week by education levels. See Tables B1 to B4 to the definitions of activities Difference between genders, calculated as the time devoted to paid work, unpaid work, and total work by men less time spent by women in these activities, considering education level. Primary education is equivalent to less than a high school degree, secondary education is equivalent to high school degree and university education is equivalent to more than a high school degree. P-value for the differences in parentheses. Demographic weights by Katz and Murphy (1992), Ecuador considered as reference country. Standard deviations in parentheses 
Table 3.2 Differences by gender considering education levels in time devoted to paid work, unpaid work, childcare, and total work for

Ecuador, Mexico, Panama, Peru and Colombia, with the presence of minors in the household.

\begin{tabular}{|c|c|c|c|c|c|c|c|c|c|c|c|c|c|c|c|c|c|c|}
\hline \multirow{3}{*}{ Ecuador } & \multicolumn{4}{|c|}{ Paid work } & \multicolumn{4}{|c|}{ Unpaid work } & \multicolumn{4}{|c|}{ Childcare } & \multicolumn{4}{|c|}{ Total Work } & \multicolumn{2}{|c|}{ Observations } \\
\hline & Men & Women & Diff & P-Value & Men & Women & Diff & P-Value & Men & Women & $\begin{array}{l}\text { Diff } \\
\end{array}$ & P-Value & Men & Women & Diff & P-Value & Men & Women \\
\hline & & & & & & & & & & & & & & & & & & \\
\hline $\begin{array}{l}\overline{\text { Primary }} \\
\text { Education }\end{array}$ & $\begin{array}{c}49.07 \\
(15.66)\end{array}$ & $\begin{array}{c}19.73 \\
(24.25)\end{array}$ & 29.34 & $(0.0000)$ & $\begin{array}{c}8.08 \\
(9.22)\end{array}$ & $\begin{array}{c}40.06 \\
(18.99)\end{array}$ & -31.98 & $(0.0000)$ & $\begin{array}{l}1.78 \\
(3.56)\end{array}$ & $\begin{array}{c}7.84 \\
(8.28)\end{array}$ & -6.06 & $(0.0000)$ & $\begin{array}{c}58.94 \\
(17.92)\end{array}$ & $\begin{array}{c}67.63 \\
(29.80)\end{array}$ & -8.69 & $(0.0000)$ & 5205 & 6643 \\
\hline $\begin{array}{l}\text { Secundary } \\
\text { Education }\end{array}$ & $\begin{array}{c}51.19 \\
(15.84)\end{array}$ & $\begin{array}{c}22.13 \\
(24.95)\end{array}$ & 29.06 & $(0.0000)$ & $\begin{array}{c}7.43 \\
(8.73)\end{array}$ & $\begin{array}{c}36.45 \\
(18.27)\end{array}$ & -29.02 & $(0.0000)$ & $\begin{array}{c}2.53 \\
(4.24)\end{array}$ & $\begin{array}{c}9.41 \\
(8.82)\end{array}$ & -6.89 & $(0.0000)$ & $\begin{array}{c}61.14 \\
(18.36)\end{array}$ & $\begin{array}{c}67.99 \\
(28.65)\end{array}$ & -6.86 & $(0.0000)$ & 1599 & 1925 \\
\hline $\begin{array}{l}\text { University } \\
\text { Education }\end{array}$ & $\begin{array}{c}48.24 \\
(14.16)\end{array}$ & $\begin{array}{c}33.51 \\
(21.63)\end{array}$ & 14.72 & $(0.0000)$ & $\begin{array}{c}9.43 \\
(9.75)\end{array}$ & $\begin{array}{c}31.40 \\
(17.55)\end{array}$ & -21.97 & $(0.0000)$ & $\begin{array}{c}2.96 \\
(4.53)\end{array}$ & $\begin{array}{c}8.75 \\
(8.63)\end{array}$ & -5.80 & $(0.0000)$ & $\begin{array}{c}60.62 \\
(17.44)\end{array}$ & $\begin{array}{c}73.67 \\
(26.31)\end{array}$ & -13.05 & $(0.0000)$ & 1003 & 1217 \\
\hline $\begin{array}{l}\text { Total } \\
\text { México }\end{array}$ & & & & & & & & & & & & & & & & & 7807 & 9785 \\
\hline $\begin{array}{l}\text { Primary } \\
\text { Education }\end{array}$ & $\begin{array}{c}50.00 \\
(22.13)\end{array}$ & $\begin{array}{c}17.59 \\
(24.89)\end{array}$ & 32.41 & $(0.0000)$ & $\begin{array}{c}9.90 \\
(10.41)\end{array}$ & $\begin{array}{c}42.24 \\
(20.04)\end{array}$ & -32.34 & $(0.0000)$ & $\begin{array}{c}1.66 \\
(3.41)\end{array}$ & $\begin{array}{c}6.15 \\
(8.23)\end{array}$ & -4.48 & $(0.0000)$ & $\begin{array}{c}61.57 \\
(23.11)\end{array}$ & $\begin{array}{c}65.99 \\
(27.26)\end{array}$ & -4.42 & $(0.0000)$ & 6348 & 7987 \\
\hline $\begin{array}{l}\text { Secundary } \\
\text { Education }\end{array}$ & $\begin{array}{c}53.25 \\
(20.45)\end{array}$ & $\begin{array}{c}26.35 \\
(26.08)\end{array}$ & 26.90 & $(0.0000)$ & $\begin{array}{c}11.05 \\
(10.57)\end{array}$ & $\begin{array}{c}37.38 \\
(18.99)\end{array}$ & -26.33 & $(0.0000)$ & $\begin{array}{c}2.46 \\
(4.13)\end{array}$ & $\begin{array}{c}7.80 \\
(8.83)\end{array}$ & -5.34 & $(0.0000)$ & $\begin{array}{l}66.76 \\
(21.91)\end{array}$ & $\begin{array}{c}71.52 \\
(26.83)\end{array}$ & -4.77 & $(0.0000)$ & 1154 & 1614 \\
\hline $\begin{array}{l}\text { University } \\
\text { Education }\end{array}$ & $\begin{array}{c}50.80 \\
(18.59)\end{array}$ & $\begin{array}{c}32.11 \\
(22.32)\end{array}$ & 18.69 & $(0.0000)$ & $\begin{array}{l}10.88 \\
(9.00)\end{array}$ & $\begin{array}{c}32.74 \\
(19.13)\end{array}$ & -21.86 & $(0.0000)$ & $\begin{array}{c}2.59 \\
(4.04)\end{array}$ & $\begin{array}{c}7.44 \\
(8.86)\end{array}$ & -4.83 & $(0.0000)$ & $\begin{array}{c}64.29 \\
(19.80)\end{array}$ & $\begin{array}{c}72.29 \\
(25.77)\end{array}$ & -8.00 & $(0.0000)$ & 1367 & 1368 \\
\hline $\begin{array}{l}\text { Total } \\
\text { Perú }\end{array}$ & & & & & & & & & & & & & & & & & 8869 & 10969 \\
\hline $\begin{array}{l}\text { Primary } \\
\text { Education }\end{array}$ & $\begin{array}{c}50.62 \\
(17.98)\end{array}$ & $\begin{array}{l}22.27 \\
(22.37)\end{array}$ & 28.35 & $(0.0000)$ & $\begin{array}{l}13.33 \\
(9.81)\end{array}$ & $\begin{array}{c}40.31 \\
(15.28)\end{array}$ & -26.98 & $(0.0000)$ & $\begin{array}{l}2.47 \\
(3.11)\end{array}$ & $\begin{array}{c}6.47 \\
(7.80)\end{array}$ & -3.98 & $(0.0000)$ & $\begin{array}{c}66.43 \\
(16.41)\end{array}$ & $\begin{array}{c}69.04 \\
(19.62)\end{array}$ & -2.62 & $(0.0002)$ & 1163 & 1674 \\
\hline $\begin{array}{l}\text { Secundary } \\
\text { Education }\end{array}$ & $\begin{array}{c}54.21 \\
(17.46)\end{array}$ & $\begin{array}{c}25.87 \\
(25.48)\end{array}$ & 28.34 & $(0.0000)$ & $\begin{array}{l}11.22 \\
(8.63)\end{array}$ & $\begin{array}{c}34.30 \\
(15.31)\end{array}$ & -23.08 & $(0.0000)$ & $\begin{array}{c}2.92 \\
(3.52)\end{array}$ & $\begin{array}{c}8.23 \\
(8.24)\end{array}$ & -5.30 & $(0.0000)$ & $\begin{array}{c}68.36 \\
(16.77)\end{array}$ & $\begin{array}{c}68.41 \\
(19.59)\end{array}$ & -0.05 & $(0.9610)$ & 796 & 731 \\
\hline $\begin{array}{l}\text { University } \\
\text { Education }\end{array}$ & $\begin{array}{c}51.60 \\
(19.75)\end{array}$ & $\begin{array}{c}28.89 \\
(23.73)\end{array}$ & 22.70 & $(0.0000)$ & $\begin{array}{l}11.42 \\
(7.89)\end{array}$ & $\begin{array}{c}30.25 \\
(14.68)\end{array}$ & -18.82 & $(0.0000)$ & $\begin{array}{c}3.37 \\
(3.77)\end{array}$ & $\begin{array}{c}8.20 \\
(8.48)\end{array}$ & -4.83 & $(0.0000)$ & $\begin{array}{c}66.39 \\
(18.83)\end{array}$ & $\begin{array}{c}67.35 \\
(19.70)\end{array}$ & -0.96 & $(0.4091)$ & 543 & 564 \\
\hline $\begin{array}{l}\text { Total } \\
\text { Colombia }\end{array}$ & & & & & & & & & & & & & & & & & 2502 & 2969 \\
\hline $\begin{array}{l}\text { Primary } \\
\text { Education }\end{array}$ & $\begin{array}{c}48.68 \\
(31.35)\end{array}$ & $\begin{array}{c}16.76 \\
(27.63)\end{array}$ & 31.92 & $(0.0000)$ & $\begin{array}{c}7.71 \\
(12.24)\end{array}$ & $\begin{array}{c}34.59 \\
(19.21)\end{array}$ & -26.88 & $(0.0000)$ & $\begin{array}{c}1.98 \\
(4.69)\end{array}$ & $\begin{array}{c}5.83 \\
(8.87)\end{array}$ & -3.85 & $(0.0000)$ & $\begin{array}{l}58.37 \\
(29.28)\end{array}$ & $\begin{array}{c}57.17 \\
(25.87)\end{array}$ & 1.19 & $(0.0006)$ & 11311 & 13790 \\
\hline $\begin{array}{l}\text { Secundary } \\
\text { Education }\end{array}$ & $\begin{array}{c}49.47 \\
(32.62)\end{array}$ & $\begin{array}{c}24.10 \\
(30.93)\end{array}$ & 25.36 & $(0.0000)$ & $\begin{array}{c}7.51 \\
(11.83)\end{array}$ & $\begin{array}{c}29.57 \\
(19.54)\end{array}$ & -22.06 & $(0.0000)$ & $\begin{array}{c}2.67 \\
(5.60)\end{array}$ & $\begin{array}{c}7.39 \\
(10.12)\end{array}$ & -4.72 & $(0.0000)$ & $\begin{array}{c}59.64 \\
(30.04)\end{array}$ & $\begin{array}{c}61.07 \\
(27.37)\end{array}$ & -1.42 & $(0.0044)$ & 5678 & 7753 \\
\hline $\begin{array}{l}\text { University } \\
\text { Education } \\
\text { Total }\end{array}$ & $\begin{array}{c}45.14 \\
(32.24)\end{array}$ & $\begin{array}{l}30.26 \\
(31.62)\end{array}$ & 14.88 & $(0.0000)$ & $\begin{array}{c}9.14 \\
(12.90)\end{array}$ & $\begin{array}{c}23.57 \\
(18.98)\end{array}$ & -14.42 & $(0.0000)$ & $\begin{array}{c}3.31 \\
(6.46)\end{array}$ & $\begin{array}{c}6.77 \\
(9.99)\end{array}$ & -3.45 & $(0.0000)$ & $\begin{array}{c}57.59 \\
(29.90)\end{array}$ & $\begin{array}{c}60.59 \\
(28.38)\end{array}$ & -3.00 & $(0.0000)$ & $\begin{array}{r}4368 \\
21357\end{array}$ & $\begin{array}{r}7164 \\
28707\end{array}$ \\
\hline
\end{tabular}

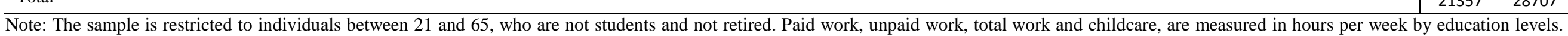

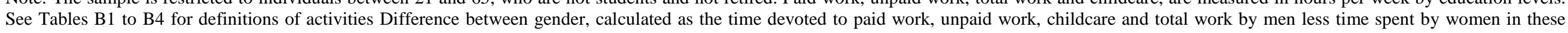

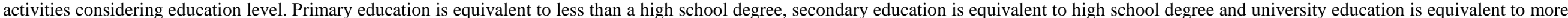

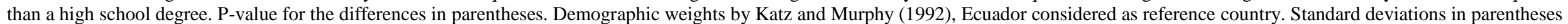


Table 4 Country-variant factors.

\begin{tabular}{lccccc}
\hline Country & $\begin{array}{c}\text { GDP Per } \\
\text { Capita } \\
\text { (US dollars) }\end{array}$ & $\begin{array}{c}\text { Female } \\
\text { unemployment } \\
\text { rate }\end{array}$ & Sex Ratio & $\begin{array}{c}\text { Total Fertility } \\
\text { rate }\end{array}$ & $\begin{array}{c}\text { Crude } \\
\text { divorce rate }\end{array}$ \\
\hline Ecuador & 5310.63 & 5.6 & 100.91 & 2.60 & 1.16 \\
Mexico & 7979.16 & 5.2 & 102.61 & 2.30 & 0.8 \\
Peru & 5221.06 & 4.3 & 99.8 & 2.50 & 0.31 \\
Colombia & 8131.12 & 14.2 & 101.6 & 2.22 & 0.39
\end{tabular}

Note. The values correspond to the years of time-use surveys. GDP per capita in current US dollars, the information comes from the IDB for Ecuador, Mexico, Peru and DANE (National Administrative Department of Statistics) for Colombia without the Amazon Region or San Andrés. GDP per capita is gross domestic product divided by the midyear population. Female unemployment rate is obtained from the World Bank for Ecuador, Peru and Colombia and from INEGI (National Institute of Statistics and Geography) for Mexico. Unemployment is the proportion of the labor force that is unemployed but available for and seeking employment. Sex Ratio comes from INEC (National Institute of Statistics and Census) for Ecuador, INEGI (National Institute of Statistics and Geography) for Mexico, INEI (National Institute of Statistics and Informatics) for Peru and DANE (National Administrative Department of Statistics) for Colombia. Sex ratios are defined as the number of women per 100 men. Fertility Rate information comes from the World Bank for Ecuador, Mexico, Peru and DANE (National Administrative Department of Statistics) for Colombia without the Amazon Region or San Andrés. Total fertility rate represents the number of children that would be born to a woman if she were to live to the end of her childbearing years and bear children in accordance with current agespecific fertility rates. Crude divorce rate is obtained from INEC (National Institute of Statistics and Census) for Ecuador, INEGI (National Institute of Statistics and Geography) for Mexico, INEI (National Institute of Statistics and Informatics) for Peru, DANE (National Administrative Department of Statistics for Colombia) and Superintendency of Notaries and Registry for Colombia without the Amazon Region or San Andrés. Crude Divorce Rates are defined as the number of divorces occurring among the population of a given geographical area during a given year, per 1,000 mid-year total population of the given geographical area during the same year. 
Table 5 OLS regressions on the time devoted to total work considering gender and country-variant factors.

\begin{tabular}{|c|c|c|c|c|c|c|c|}
\hline & $\begin{array}{c}\text { (1) } \\
\text { Gender }\end{array}$ & $\begin{array}{c}(2) \\
\text { Gender } \\
\text { and GDP } \\
\text { per } \\
\text { capita }\end{array}$ & $\begin{array}{c}(3) \\
\text { Gender } \\
\text { and } \\
\text { Female } \\
\text { unemploy- } \\
\text { ment rate }\end{array}$ & $\begin{array}{c}\text { (4) } \\
\text { Gender } \\
\text { and sex } \\
\text { ratio }\end{array}$ & $\begin{array}{c}\text { (5) } \\
\text { Gender } \\
\text { and } \\
\text { fertility } \\
\text { rate }\end{array}$ & $\begin{array}{c}\text { (6) } \\
\text { Gender } \\
\text { and } \\
\text { crude } \\
\text { divorce } \\
\text { rate } \\
\end{array}$ & $\begin{array}{c}\text { (7) } \\
\text { Gender } \\
\text { and } \\
\text { country } \\
\text { varying } \\
\text { factors } \\
\end{array}$ \\
\hline Woman & $\begin{array}{c}1.577 * * * \\
(0.154)\end{array}$ & $\begin{array}{c}1.587 * * * \\
(0.154)\end{array}$ & $\begin{array}{c}1.578 * * * \\
(0.154)\end{array}$ & $\begin{array}{c}1.560^{* * *} \\
(0.154)\end{array}$ & $\begin{array}{c}1.570 * * * \\
(0.154)\end{array}$ & $\begin{array}{c}1.540 * * * \\
(0.154)\end{array}$ & $\begin{array}{c}.555^{* * *} \\
(0.154)\end{array}$ \\
\hline University Education & $\begin{array}{c}-1.167 * * * \\
(0.229)\end{array}$ & $\begin{array}{c}-1.247^{* * *} \\
(0.229)\end{array}$ & $\begin{array}{c}-1.161^{* * *} \\
(0.229)\end{array}$ & $\begin{array}{c}-1.188^{* * *} \\
(0.229)\end{array}$ & $\begin{array}{c}-1.233^{* * *} \\
(0.229)\end{array}$ & $\begin{array}{c}-1.259 * * * \\
(0.229)\end{array}$ & $\begin{array}{c}-1.291 * * * \\
(0.229)\end{array}$ \\
\hline Age & $\begin{array}{l}1.652^{* * *} \\
(0.0460)\end{array}$ & $\begin{array}{c}1.645^{* * *} \\
(0.0459)\end{array}$ & $\begin{array}{l}1.651 * * * \\
(0.0460)\end{array}$ & $\begin{array}{l}1.655^{* * *} \\
(0.0460)\end{array}$ & $\begin{array}{c}1.645^{* * *} \\
(0.0460)\end{array}$ & $\begin{array}{c}1.646 * * * \\
(0.0460)\end{array}$ & $\begin{array}{c}1.644^{* * *} \\
(0.0459)\end{array}$ \\
\hline Age squared & $\begin{array}{c}-2.162 * * * \\
(0.0546)\end{array}$ & $\begin{array}{c}-2.155^{* * *} \\
(0.0546)\end{array}$ & $\begin{array}{c}-2.160 * * * \\
(0.0546)\end{array}$ & $\begin{array}{c}-2.166^{* * *} \\
(0.0546)\end{array}$ & $\begin{array}{c}-2.155^{* * *} \\
(0.0547)\end{array}$ & $\begin{array}{c}-2.157^{* * *} \\
(0.0546)\end{array}$ & $\begin{array}{c}-2.156 * * * \\
(0.0546)\end{array}$ \\
\hline Number of household members & $\begin{array}{c}-1.016^{* * *} \\
(0.0449)\end{array}$ & $\begin{array}{c}-0.999 * * * \\
(0.0449)\end{array}$ & $\begin{array}{c}-1.014 * * * \\
(0.0449)\end{array}$ & $\begin{array}{c}-1.018^{* * *} \\
(0.0449)\end{array}$ & $\begin{array}{c}-0.984^{* * *} \\
(0.0450)\end{array}$ & $\begin{array}{c}-0.965^{* * *} \\
(0.0450)\end{array}$ & $\begin{array}{c}-0.979 * * * \\
(0.0450)\end{array}$ \\
\hline GDP per capita/1000 & - & $\begin{array}{c}0.578 * * * \\
(0.0343)\end{array}$ & $\begin{array}{l}- \\
-\end{array}$ & - & $\begin{array}{l}- \\
-\end{array}$ & - & $\begin{array}{c}0.722^{* * *} \\
(0.0590)\end{array}$ \\
\hline Female unemployment rate & - & - & $\begin{array}{c}0.521 * * * \\
(0.127)\end{array}$ & - & - & - & $\begin{array}{c}0.855^{* * *} \\
(0.147)\end{array}$ \\
\hline Sex ratio & - & - & $\begin{array}{l}- \\
-\end{array}$ & $\begin{array}{c}0.360^{* * *} \\
(0.0389)\end{array}$ & - & - & $\begin{array}{c}0.253^{* * *} \\
(0.0535)\end{array}$ \\
\hline Fertility rate & - & $\begin{array}{l}- \\
-\end{array}$ & - & - & $\begin{array}{c}-5.333^{* * *} \\
(0.393)\end{array}$ & - & $\begin{array}{c}4.358 * * * \\
(0.843)\end{array}$ \\
\hline Crude divorce rate & $\begin{array}{l}- \\
-\end{array}$ & $\begin{array}{l}- \\
-\end{array}$ & $\begin{array}{l}- \\
-\end{array}$ & - & - & $\begin{array}{c}8.609 * * * \\
(0.522)\end{array}$ & $\begin{array}{c}6.894 * * * \\
(0.830)\end{array}$ \\
\hline R-squared & 0.053 & 0.056 & 0.053 & 0.054 & 0.055 & 0.055 & 0.057 \\
\hline Observations & 135.700 & 135.700 & 135.700 & 135.700 & 135.700 & 135.700 & 135.700 \\
\hline
\end{tabular}

Note: The sample is restricted to individuals between 21 and 65 who are not students and not retired. Total work is measured in hours per week. See Tables B1 to B4 for definitions of categories that make up total work. Primary education is equivalent to less than a high school degree, secondary education is equivalent to high school degree and university education is equivalent to more than a high school degree. * Significant at the $90 \%$ level; ** Significant at the 95\% level; *** Significant at the 99\% level. Demographic weights by Katz and Murphy (1992), Ecuador considered as reference country. Standard deviations in parentheses 
Table 6 OLS regressions on the time devoted to total work considering gender, country-variant factors and egalitarian social norms.

\begin{tabular}{|c|c|c|c|}
\hline & $\begin{array}{c}\text { (1) } \\
\text { Gender }\end{array}$ & $\begin{array}{c}(2) \\
\text { Country } \\
\text { varying factors }\end{array}$ & $\begin{array}{c}\text { (3) } \\
\text { Egalitarian } \\
\text { social norms }\end{array}$ \\
\hline Woman & $\begin{array}{c}1.577 * * * \\
(0.154)\end{array}$ & $\begin{array}{c}1.555^{* * * *} \\
(0.154)\end{array}$ & $\begin{array}{c}-0.0230 \\
(0.202)\end{array}$ \\
\hline Primary Education & $\begin{array}{c}-1.415^{* * * *} \\
(0.194)\end{array}$ & $\begin{array}{c}-1.271 * * * \\
(0.194)\end{array}$ & $\begin{array}{c}-1.286 * * * \\
(0.194)\end{array}$ \\
\hline University Education & $\begin{array}{c}-1.167 * * * \\
(0.229)\end{array}$ & $\begin{array}{c}-1.291 * * * \\
(0.229)\end{array}$ & $\begin{array}{c}-1.282^{* * *} \\
(0.229)\end{array}$ \\
\hline Age & $\begin{array}{l}1.652 * * * \\
(0.0460)\end{array}$ & $\begin{array}{l}1.644 * * * \\
(0.0459)\end{array}$ & $\begin{array}{l}1.643 * * * \\
(0.0459)\end{array}$ \\
\hline Age squared & $\begin{array}{c}-2.162 * * * \\
(0.0546)\end{array}$ & $\begin{array}{c}-2.156 * * * \\
(0.0546)\end{array}$ & $\begin{array}{c}-2.156^{* * *} \\
(0.0545)\end{array}$ \\
\hline Presence of minors & $\begin{array}{c}5.866 * * * \\
(0.202)\end{array}$ & $\begin{array}{c}5.907 * * * \\
(0.202)\end{array}$ & $\begin{array}{c}5.897 * * * \\
(0.202)\end{array}$ \\
\hline Number of household members & $\begin{array}{c}-1.016^{* * *} \\
(0.0449)\end{array}$ & $\begin{array}{c}-0.979 * * * \\
(0.0450)\end{array}$ & $\begin{array}{c}-0.978 * * * \\
(0.0450)\end{array}$ \\
\hline GDP per capita/1000 & - & $\begin{array}{c}0.722 * * * \\
(0.0590)\end{array}$ & $\begin{array}{l}1.001 * * * \\
(0.0644)\end{array}$ \\
\hline Female unemployment rate & $\begin{array}{l}- \\
-\end{array}$ & $\begin{array}{c}0.855^{* * *} \\
(0.147)\end{array}$ & $\begin{array}{c}0.786 * * * \\
(0.147)\end{array}$ \\
\hline Sex ratio & $\begin{array}{l}- \\
-\end{array}$ & $\begin{array}{c}0.253 * * * \\
(0.0535)\end{array}$ & $\begin{array}{c}0.289 * * * \\
(0.0537)\end{array}$ \\
\hline Fertility rate & $\begin{array}{l}- \\
-\end{array}$ & $\begin{array}{c}4.358 * * * \\
(0.843)\end{array}$ & $\begin{array}{c}9.107 * * * \\
(0.949)\end{array}$ \\
\hline Crude divorce rate & $\begin{array}{l}- \\
-\end{array}$ & $\begin{array}{c}6.894 * * * \\
(0.830)\end{array}$ & $\begin{array}{c}7.394 * * * \\
(0.833)\end{array}$ \\
\hline Egalitarian index & - & - & $\begin{array}{c}12.15^{* * * *} \\
(1.049)\end{array}$ \\
\hline Mexico & $\begin{array}{c}0.728 * * * \\
(0.225)\end{array}$ & $\begin{array}{c}3.027 * * * \\
(0.617)\end{array}$ & $\begin{array}{c}3.848 * * * \\
(0.621)\end{array}$ \\
\hline Peru & $\begin{array}{c}4.069 * * * \\
(0.285)\end{array}$ & $\begin{array}{c}12.35 * * * \\
(0.823)\end{array}$ & $\begin{array}{c}12.12 * * * \\
(0.822)\end{array}$ \\
\hline Colombia & $\begin{array}{c}-6.538 * * * \\
(0.195)\end{array}$ & $\begin{array}{c}-8.485^{* * *} \\
(1.780)\end{array}$ & $\begin{array}{c}-7.491 * * * \\
(1.783)\end{array}$ \\
\hline Constant & $\begin{array}{c}35.26 * * * \\
(0.943)\end{array}$ & $\begin{array}{c}-18.84 * * * \\
(5.227)\end{array}$ & $\begin{array}{c}-70.36^{* * *} \\
(7.067)\end{array}$ \\
\hline R-squared & 0.053 & 0.057 & 0.058 \\
\hline Observations & 135.700 & 135.700 & 135.700 \\
\hline
\end{tabular}

Note: The sample is restricted to individuals between 21 and 65 who are not students and not retired). Total work is measured in hours per week. See Tables B1 to B4 for definitions of categories that make up total work. Primary education is equivalent to less than a high school degree, secondary education is equivalent to high school degree and university education is equivalent to more than a high school degree. * Significant at the $90 \%$ level; ** Significant at the 95\% level; *** Significant at the 99\% level. Demographic weights by Katz and Murphy (1992), Ecuador considered as reference country. Standard deviations in parentheses 
Table 7 OLS regressions on the time devoted to total work considering gender, country- variant factors and egalitarian social norms. Education levels separately, without the presence of minors in the household.

\begin{tabular}{|c|c|c|c|c|c|c|}
\hline & $\begin{array}{c}\text { (1) } \\
\text { Primary } \\
\text { Education }\end{array}$ & $\begin{array}{c}\text { (2) } \\
\text { Primary } \\
\text { Education } \\
\text { with } \\
\text { Egalitarian } \\
\text { Index } \\
\end{array}$ & $\begin{array}{c}\text { (3) } \\
\text { Secundary } \\
\text { Education }\end{array}$ & $\begin{array}{c}(4) \\
\text { Secundary } \\
\text { Education } \\
\text { with } \\
\text { Egalitarian } \\
\text { Index } \\
\end{array}$ & $\begin{array}{c}\text { (5) } \\
\text { University } \\
\text { Education }\end{array}$ & $\begin{array}{c}(6) \\
\text { University } \\
\text { Education } \\
\text { with } \\
\text { Egalitarian } \\
\text { Index } \\
\end{array}$ \\
\hline Woman & $\begin{array}{c}-2.423^{* * *} \\
(0.380)\end{array}$ & $\begin{array}{c}-5.450 * * * \\
(0.508)\end{array}$ & $\begin{array}{l}-0.329 \\
(0.629)\end{array}$ & $\begin{array}{c}-2.397 * * * \\
(0.887)\end{array}$ & $\begin{array}{c}1.651 * * * \\
(0.498)\end{array}$ & $\begin{array}{c}0.125 \\
(0.756)\end{array}$ \\
\hline Age & $\begin{array}{c}2.029 * * * \\
(0.119)\end{array}$ & $\begin{array}{c}2.029 * * * \\
(0.119)\end{array}$ & $\begin{array}{c}2.559 * * * \\
(0.176)\end{array}$ & $\begin{array}{c}2.552 * * * \\
(0.175)\end{array}$ & $\begin{array}{c}2.670 * * * \\
(0.151)\end{array}$ & $\begin{array}{c}2.671 * * * \\
(0.151)\end{array}$ \\
\hline Age squared & $\begin{array}{c}-2.383^{* * *} \\
(0.131)\end{array}$ & $\begin{array}{c}-2.384 * * * \\
(0.130)\end{array}$ & $\begin{array}{c}-3.173^{* * *} \\
(0.213)\end{array}$ & $\begin{array}{c}-3.164 * * * \\
(0.213)\end{array}$ & $\begin{array}{c}-3.124^{* * *} \\
(0.180)\end{array}$ & $\begin{array}{c}-3.125 * * * \\
(0.180)\end{array}$ \\
\hline Number of household members & $\begin{array}{c}-1.877^{* * *} \\
(0.152)\end{array}$ & $\begin{array}{c}-1.846^{* * *} \\
(0.152)\end{array}$ & $\begin{array}{c}-2.063^{* * *} \\
(0.230)\end{array}$ & $\begin{array}{c}-2.055^{* * *} \\
(0.229)\end{array}$ & $\begin{array}{c}-1.577^{* * *} \\
(0.197)\end{array}$ & $\begin{array}{c}-1.579 * * * \\
(0.197)\end{array}$ \\
\hline GDP per capita/1000 & $\begin{array}{c}0.733 * * * \\
(0.131)\end{array}$ & $\begin{array}{c}1.267 * * * \\
(0.147)\end{array}$ & $\begin{array}{c}1.107 * * * \\
(0.219)\end{array}$ & $\begin{array}{c}1.479 * * * \\
(0.248)\end{array}$ & $\begin{array}{l}0.0559 \\
(0.201)\end{array}$ & $\begin{array}{c}0.329 \\
(0.229)\end{array}$ \\
\hline Female unemployment rate & $\begin{array}{l}0.683 * \\
(0.359)\end{array}$ & $\begin{array}{c}0.550 \\
(0.359)\end{array}$ & $\begin{array}{c}0.0872 \\
(0.757)\end{array}$ & $\begin{array}{r}-0.0274 \\
(0.757)\end{array}$ & $\begin{array}{c}0.674 \\
(0.491)\end{array}$ & $\begin{array}{c}0.591 \\
(0.492)\end{array}$ \\
\hline Sex ratio & $\begin{array}{c}0.278^{* *} \\
(0.129)\end{array}$ & $\begin{array}{c}0.329 * * \\
(0.129)\end{array}$ & $\begin{array}{l}-0.102 \\
(0.231)\end{array}$ & $\begin{array}{c}-0.0842 \\
(0.231)\end{array}$ & $\begin{array}{c}0.403^{* *} \\
(0.176)\end{array}$ & $\begin{array}{c}0.416^{* *} \\
(0.176)\end{array}$ \\
\hline Fertility rate & $\begin{array}{c}6.560 * * * \\
(1.977)\end{array}$ & $\begin{array}{c}15.86 * * * \\
(2.301)\end{array}$ & $\begin{array}{c}10.46^{* * *} \\
(3.259)\end{array}$ & $\begin{array}{c}16.76^{* * *} \\
(3.843)\end{array}$ & $\begin{array}{l}-4.174 \\
(2.820)\end{array}$ & $\begin{array}{c}0.251 \\
(3.368)\end{array}$ \\
\hline Crude divorce rate & $\begin{array}{l}3.324 * \\
(2.010)\end{array}$ & $\begin{array}{c}4.588 * * \\
(2.018)\end{array}$ & $\begin{array}{c}10.56 * * * \\
(3.589)\end{array}$ & $\begin{array}{c}11.39 * * * \\
(3.611)\end{array}$ & $\begin{array}{l}-0.233 \\
(2.984)\end{array}$ & $\begin{array}{l}0.0821 \\
(2.998)\end{array}$ \\
\hline Egalitarian index & $\begin{array}{l}- \\
-\end{array}$ & $\begin{array}{c}22.88 * * * \\
(2.655)\end{array}$ & $\begin{array}{l}- \\
-\end{array}$ & $\begin{array}{c}15.80 * * * \\
(4.727)\end{array}$ & - & $\begin{array}{c}11.77 * * * \\
(4.419)\end{array}$ \\
\hline Mexico & $\begin{array}{c}-0.305 \\
(1.478)\end{array}$ & $\begin{array}{c}1.608 \\
(1.495)\end{array}$ & $\begin{array}{c}8.711 * * * \\
(2.725)\end{array}$ & $\begin{array}{c}9.806 * * * \\
(2.765)\end{array}$ & $\begin{array}{c}-0.990 \\
(2.265)\end{array}$ & $\begin{array}{c}-0.288 \\
(2.297)\end{array}$ \\
\hline Peru & $\begin{array}{c}11.88^{* * *} \\
(2.052)\end{array}$ & $\begin{array}{c}11.78 * * * \\
(2.040)\end{array}$ & $\begin{array}{c}16.50 * * * \\
(3.664)\end{array}$ & $\begin{array}{c}16.05 * * * \\
(3.645)\end{array}$ & $\begin{array}{c}3.855 \\
(3.143)\end{array}$ & $\begin{array}{c}3.407 \\
(3.136)\end{array}$ \\
\hline Colombia & $\begin{array}{c}-9.116^{* *} \\
(4.337)\end{array}$ & $\begin{array}{l}-6.713 \\
(4.343)\end{array}$ & $\begin{array}{c}3.016 \\
(8.535)\end{array}$ & $\begin{array}{c}4.652 \\
(8.560)\end{array}$ & $\begin{array}{c}-18.44^{* * *} \\
(6.007)\end{array}$ & $\begin{array}{c}-17.48 * * * \\
(6.036)\end{array}$ \\
\hline Constant & $\begin{array}{c}-31.14 * * \\
(12.79)\end{array}$ & $\begin{array}{c}-61.61^{* * *} \\
(13.49)\end{array}$ & $\begin{array}{l}-17.36 \\
(23.02)\end{array}$ & $\begin{array}{l}-35.89 \\
(23.85)\end{array}$ & $\begin{array}{c}-21.66 \\
(17.90)\end{array}$ & $\begin{array}{c}-34.57^{*} \\
(18.75)\end{array}$ \\
\hline R-squared & 0.048 & 0.051 & 0.070 & 0.071 & 0.078 & 0.079 \\
\hline Observations & 22.044 & 22.044 & 8.363 & 8.363 & 12.328 & 12.328 \\
\hline
\end{tabular}

Note: The sample is restricted to individuals between 21 and 65 who are not students and not retired. Total work is measured in hours per week. See Tables B1 to B4 for definitions of categories that make up the total work. Primary education is equivalent to less than a high school degree, secondary education is equivalent to high school degree and university education is equivalent to more than a high school degree. * Significant at the $90 \%$ level; ** Significant at the 95\% level; *** Significant at the 99\% level. Demographic weights by Katz and Murphy (1992), Ecuador considered as reference country. Standard deviations in parentheses 
Table 8 OLS regressions on the time devoted to total work considering gender, country- variant factors and egalitarian social norms. Education levels separately, with the presence of minors in the household.

\begin{tabular}{|c|c|c|c|c|c|c|}
\hline & $\begin{array}{c}\text { (1) } \\
\text { Primary } \\
\text { Education }\end{array}$ & $\begin{array}{c}(2) \\
\text { Primary } \\
\text { Education } \\
\text { with } \\
\text { Egalitarian } \\
\text { Index } \\
\end{array}$ & $\begin{array}{c}\text { (3) } \\
\text { Secundary } \\
\text { Education }\end{array}$ & $\begin{array}{c}\text { (4) } \\
\text { Secundary } \\
\text { Education } \\
\text { with } \\
\text { Egalitarian } \\
\text { Index } \\
\end{array}$ & $\begin{array}{c}\text { (5) } \\
\text { University } \\
\text { Education }\end{array}$ & $\begin{array}{c}(6) \\
\text { University } \\
\text { Education } \\
\text { with } \\
\text { Egalitarian } \\
\text { Index } \\
\end{array}$ \\
\hline Woman & $\begin{array}{c}1.623^{* * *} \\
(0.234)\end{array}$ & $\begin{array}{l}0.0910 \\
(0.297)\end{array}$ & $\begin{array}{c}2.598 * * * \\
(0.377)\end{array}$ & $\begin{array}{c}1.941^{* * *} \\
(0.501)\end{array}$ & $\begin{array}{c}5.238 * * * \\
(0.417)\end{array}$ & $\begin{array}{c}4.577 * * * \\
(0.594)\end{array}$ \\
\hline Age & $\begin{array}{c}1.472 * * * \\
(0.0712)\end{array}$ & $\begin{array}{l}1.470 * * * \\
(0.0712)\end{array}$ & $\begin{array}{c}2.051^{* * * *} \\
(0.134)\end{array}$ & $\begin{array}{c}2.050 * * * \\
(0.134)\end{array}$ & $\begin{array}{c}2.371^{* * *} \\
(0.149)\end{array}$ & $\begin{array}{c}2.369 * * * \\
(0.149)\end{array}$ \\
\hline Age squared & $\begin{array}{c}-2.044 * * * \\
(0.0846)\end{array}$ & $\begin{array}{c}-2.043^{* * *} \\
(0.0846)\end{array}$ & $\begin{array}{c}-2.782^{* * *} \\
(0.176)\end{array}$ & $\begin{array}{c}-2.780 * * * \\
(0.176)\end{array}$ & $\begin{array}{c}-3.032 * * * \\
(0.188)\end{array}$ & $\begin{array}{c}-3.030 * * * \\
(0.188)\end{array}$ \\
\hline Number of household members & $\begin{array}{c}-0.602 * * * \\
(0.0600)\end{array}$ & $\begin{array}{c}-0.603^{* * *} \\
(0.0599)\end{array}$ & $\begin{array}{c}-1.017^{* * *} \\
(0.104)\end{array}$ & $\begin{array}{c}-1.018^{* * *} \\
(0.104)\end{array}$ & $\begin{array}{c}-1.475^{* * *} \\
(0.129)\end{array}$ & $\begin{array}{c}-1.473 * * * \\
(0.129)\end{array}$ \\
\hline GDP per capita/1000 & $\begin{array}{c}0.794 * * * \\
(0.0894)\end{array}$ & $\begin{array}{l}1.064 * * * \\
(0.0962)\end{array}$ & $\begin{array}{c}0.590 * * * \\
(0.140)\end{array}$ & $\begin{array}{c}0.710^{* * *} \\
(0.155)\end{array}$ & $\begin{array}{c}0.541 * * * \\
(0.169)\end{array}$ & $\begin{array}{c}0.651^{* * *} \\
(0.187)\end{array}$ \\
\hline Female unemployment rate & $\begin{array}{c}0.884^{* * *} \\
(0.203)\end{array}$ & $\begin{array}{c}0.824 * * * \\
(0.203)\end{array}$ & $\begin{array}{c}0.943^{* *} \\
(0.440)\end{array}$ & $\begin{array}{c}0.911 * * \\
(0.440)\end{array}$ & $\begin{array}{c}0.549 \\
(0.436)\end{array}$ & $\begin{array}{c}0.521 \\
(0.437)\end{array}$ \\
\hline Sex ratio & $\begin{array}{c}0.319 * * * \\
(0.0765)\end{array}$ & $\begin{array}{l}0.360 * * * \\
(0.0770)\end{array}$ & $\begin{array}{c}0.194 \\
(0.156)\end{array}$ & $\begin{array}{c}0.212 \\
(0.156)\end{array}$ & $\begin{array}{c}0.0994 \\
(0.154)\end{array}$ & $\begin{array}{c}0.114 \\
(0.153)\end{array}$ \\
\hline Fertility rate & $\begin{array}{c}5.678 * * * \\
(1.297)\end{array}$ & $\begin{array}{c}10.35^{* * *} \\
(1.434)\end{array}$ & $\begin{array}{l}-0.805 \\
(2.058)\end{array}$ & $\begin{array}{c}1.219 \\
(2.360)\end{array}$ & $\begin{array}{l}-0.334 \\
(2.342)\end{array}$ & $\begin{array}{c}1.433 \\
(2.703)\end{array}$ \\
\hline Crude divorce rate & $\begin{array}{c}9.186^{* * *} \\
(1.219)\end{array}$ & $\begin{array}{c}9.677 * * * \\
(1.221)\end{array}$ & $\begin{array}{c}5.951^{* * * *} \\
(2.179)\end{array}$ & $\begin{array}{c}6.195^{* * * *} \\
(2.194)\end{array}$ & $\begin{array}{c}3.271 \\
(2.385)\end{array}$ & $\begin{array}{c}3.273 \\
(2.387)\end{array}$ \\
\hline Egalitarian index & - & $\begin{array}{c}11.81 * * * \\
(1.489)\end{array}$ & - & $\begin{array}{c}5.170 * * \\
(2.610)\end{array}$ & $\begin{array}{l}- \\
-\end{array}$ & $\begin{array}{c}5.059 \\
(3.242)\end{array}$ \\
\hline Mexico & $\begin{array}{c}3.477^{* * *} \\
(0.900)\end{array}$ & $\begin{array}{c}4.288 * * * \\
(0.904)\end{array}$ & $\begin{array}{c}5.043 * * * \\
(1.651)\end{array}$ & $\begin{array}{c}5.380 * * * \\
(1.670)\end{array}$ & $\begin{array}{c}0.985 \\
(1.800)\end{array}$ & $\begin{array}{c}1.171 \\
(1.820)\end{array}$ \\
\hline Peru & $\begin{array}{c}14.65 * * * \\
(1.196)\end{array}$ & $\begin{array}{c}14.48 * * * \\
(1.194)\end{array}$ & $\begin{array}{c}10.70 * * * \\
(2.089)\end{array}$ & $\begin{array}{c}10.61 * * * \\
(2.085)\end{array}$ & $\begin{array}{c}3.987 \\
(2.430)\end{array}$ & $\begin{array}{c}3.662 \\
(2.413)\end{array}$ \\
\hline Colombia & $\begin{array}{c}-6.280 * * \\
(2.524)\end{array}$ & $\begin{array}{c}-5.359 * * \\
(2.525)\end{array}$ & $\begin{array}{l}-9.843^{*} \\
(5.083)\end{array}$ & $\begin{array}{l}-9.385 * \\
(5.095)\end{array}$ & $\begin{array}{c}-12.19 * * \\
(5.257)\end{array}$ & $\begin{array}{c}-12.02 * * \\
(5.268)\end{array}$ \\
\hline Constant & $\begin{array}{c}-24.84 * * * \\
(7.521)\end{array}$ & $\begin{array}{c}-41.33^{* * *} \\
(7.989)\end{array}$ & $\begin{array}{c}-0.0908 \\
(14.63)\end{array}$ & $\begin{array}{l}-7.306 \\
(15.20)\end{array}$ & $\begin{array}{c}8.749 \\
(15.43)\end{array}$ & $\begin{array}{c}2.904 \\
(15.86)\end{array}$ \\
\hline R-squared & 0.047 & 0.048 & 0.048 & 0.048 & 0.067 & 0.067 \\
\hline Observations & 54.121 & 54.121 & 21.250 & 21.250 & 17.594 & 17.594 \\
\hline
\end{tabular}

Note: The sample is restricted to individuals between 21 and 65 who are not students and not retired. Total work is measured in hours per week by education levels. See Tables B1 to B4 for definitions of categories that make up the total work. Primary education is equivalent to less than a high school degree, secondary education is equivalent to high school degree and university education is equivalent to more than a high school degree. * Significant at the $90 \%$ level; ** Significant at the 95\% level; *** Significant at the 99\% level Demographic weights by Katz and Murphy (1992), Ecuador considered as reference country. Standard deviations in parentheses 


\section{Appendix A: Demographic weighting}

Based on prior studies of individual time-use, such as Aguiar and Hurst (2007) and Gimenez-Nadal and Sevilla (2012, 2014), we maintain constant demographic composition, taking Ecuador as the reference country, for comparison with the three other countries studied, Mexico, Peru and Colombia. We divide the sample into demographic cells of five age groups (21-29, 30-39, 40-49, 50-59 and 60-65), three levels of education (primary, secondary, and university), gender, whether there are children in the household, and whether the respondent lives in a couple or not. We did not create a cell for the presence of children with respondents aged 60-65, due to the very limited presence of children in households of this age group. To calculate the constant weights, we unify the four surveys into one and calculate the percentage of the population that would be within each cell population within each survey. Following Katz and Murphy (1992), we use fixed weights to calculate weighted averages for each activity. As our analysis is based on gender we compute scaled weights to sum to one by gender. We compute the percentage of men and women residing in each cell population (based on age, education, presence of children, and life partner) and these percentages add up to one for men and women. By having the four surveys unified into one to calculate the percentage of population within each demographic cell, and using the weights provided by each survey (based on the reference country) we generate reference periods and each survey is represented in the same manner in the bulk sample.

Table A1 shows the summary statistics of the demographic variables used to calculate the constant demographic weight, mainly observed differences in education levels. 28\% of Colombian women and $21 \%$ of Peruvian women have an education level above high school, compared to $15 \%$ and $14 \%$ of Mexican and Ecuadorian women, respectively. In the case of Colombia, we also indicate that the proportion of respondents who live with a partner, and have children in the household, are both smaller than the other three countries.

It is important to note that there is a greater presence of minors in households with primary and secondary level education (approximately $71 \%$ on average) while in households whose members have university education levels, that proportion is approximately 59\% on average. Gimenez-Nadal and Sevilla (2012) show that these differences may determine changes in the distribution of time, a greater presence of 
minors in the household will mean more time dedicated to childcare. In addition, a higher education, as Becker (1965) argues, means more time spent in paid work, due to the greater opportunity cost of time. In trying to make a better comparative analysis between countries, we must control for the uncertainties caused by different proportions of the population in each demographic category, and so we sustain the use of population weights proposed by Katz and Murphy (1992).

Table A1. Summary statistics for demographic characteristics, by country

\begin{tabular}{|c|c|c|c|c|c|c|c|c|c|c|}
\hline \multirow[t]{2}{*}{ Country } & \multirow[t]{2}{*}{ Age } & \multicolumn{2}{|c|}{$\begin{array}{l}\text { Primary } \\
\text { Education }\end{array}$} & \multicolumn{2}{|c|}{$\begin{array}{l}\text { Secondary } \\
\text { Education }\end{array}$} & \multicolumn{2}{|c|}{$\begin{array}{l}\text { University } \\
\text { Education }\end{array}$} & \multirow{2}{*}{$\begin{array}{l}\text { Presence } \\
\text { of } \\
\text { Minors }\end{array}$} & \multirow[t]{2}{*}{$\begin{array}{l}\text { Living in a } \\
\text { couple }\end{array}$} & \multirow[t]{2}{*}{ Observations } \\
\hline & & Men & Women & Men & Women & Men & Women & & & \\
\hline Ecuador & $\begin{array}{l}41.22 \\
(11.99)\end{array}$ & $\begin{array}{l}0.66 \\
(0.47)\end{array}$ & $\begin{array}{l}0.68 \\
(0.47)\end{array}$ & $\begin{array}{l}0.20 \\
(0.40)\end{array}$ & $\begin{array}{l}0.19 \\
(0.39)\end{array}$ & $\begin{array}{l}0.14 \\
(0.35)\end{array}$ & $\begin{array}{l}0.14 \\
(0.34)\end{array}$ & $\begin{array}{l}0.75 \\
(0.43)\end{array}$ & $\begin{array}{l}0.72 \\
(0.45)\end{array}$ & 23345 \\
\hline Mexico & $\begin{array}{l}39.24 \\
(11.87)\end{array}$ & $\begin{array}{l}0.68 \\
(0.47)\end{array}$ & $\begin{array}{l}(0.70) \\
(0.46)\end{array}$ & $\begin{array}{l}0.13 \\
(0.34)\end{array}$ & $\begin{array}{l}0.15 \\
(0.35)\end{array}$ & $\begin{array}{l}0.19 \\
(0.39)\end{array}$ & $\begin{array}{l}0.15 \\
(0.36)\end{array}$ & $\begin{array}{l}0.69 \\
(0.46)\end{array}$ & $\begin{array}{l}0.71 \\
(0.45)\end{array}$ & 28492 \\
\hline Peru & $\begin{array}{l}40.73 \\
(11.96)\end{array}$ & $\begin{array}{l}0.45 \\
(0.50)\end{array}$ & $\begin{array}{l}0.56 \\
(0.50)\end{array}$ & $\begin{array}{l}0.31 \\
(0.46)\end{array}$ & $\begin{array}{l}0.24 \\
(0.42)\end{array}$ & $\begin{array}{l}0.24 \\
(0.43)\end{array}$ & $\begin{array}{l}0.21 \\
(0.41)\end{array}$ & $\begin{array}{l}0.75 \\
(0.43)\end{array}$ & $\begin{array}{l}0.72 \\
(0.45)\end{array}$ & 7243 \\
\hline Colombia & $\begin{array}{l}40.42 \\
(12.37)\end{array}$ & $\begin{array}{l}0.50 \\
(0.50)\end{array}$ & $\begin{array}{l}0.47 \\
(0.50)\end{array}$ & $\begin{array}{l}0.25 \\
(0.44)\end{array}$ & $\begin{array}{l}0.25 \\
(0.43)\end{array}$ & $\begin{array}{l}0.24 \\
(0.43)\end{array}$ & $\begin{array}{l}0.28 \\
(0.45)\end{array}$ & $\begin{array}{l}0.65 \\
(0.48)\end{array}$ & $\begin{array}{l}0.62 \\
(0.49)\end{array}$ & 76621 \\
\hline
\end{tabular}

Note: The sample is restricted to individuals between 21 and 65 who are not students and not retired. Primary education is equivalent to less than a high school degree, secondary education is equivalent to high school degree and university education is equivalent to more than a high school degree. Presence of minors refers to household members under age 18. Standard deviations in parentheses. 


\section{Appendix B Classification of activities}

\section{Table B1 Ecuador}

\begin{tabular}{|c|c|}
\hline Paid work & Regular work in all jobs, travel from/to all jobs, job seeking \\
\hline Unpaid work & $\begin{array}{l}\text { Preparing food, serving food, washing dishes, cleaning the place where } \\
\text { food is prepared, thresh and grinding grain, beverage preparation, } \\
\text { slaughtering of animals for consumption, bringing food to a household } \\
\text { member, turn the wood/coal stove, making preserves, make bread, } \\
\text { preparing other food products, prepare milk, dried beans, dried meat, } \\
\text { dried fish products, making beds, cleaning bathrooms, cleaning house, } \\
\text { fetch water for household consumption, wash a vehicle, littering, shoe } \\
\text { cleaning, laundry, ironing clothes, take clothes to the cleaners, fold } \\
\text { clothes, drew up or mended clothes, buy meats/vegetables/fruits, daily } \\
\text { shopping, buy medicine, buy school supplies/clothes/shoes, buy goods/ } \\
\text { appliances, buy orthopedic appliances, moving home, accommodating } \\
\text { house (terrace, closet), carry or pick up a household member to an } \\
\text { educational center, accompany household member to receive medical } \\
\text { attention, carry or pick up a household member to work, accompany a } \\
\text { household member to a special class or training, caring for sick } \\
\text { household member by day or night, carry a household member to a } \\
\text { health center, carry a household member to a therapist, prepare home } \\
\text { remedies for any household member, general home repair, repairs } \\
\text { means of transportation, appliance repair, care for farm animals, } \\
\text { milking/shearing/collect eggs, collecting water for the terrain, } \\
\text { collecting firewood/mushrooms/herbs, collect flowers and fruits, } \\
\text { hunting and fishing for consumption by household members, most } \\
\text { orchard activities (sowing, harvesting), charge government subsidies, } \\
\text { rental housing formalities, payment basic services, payment } \\
\text { formalities, order documents, supervising chores, do household } \\
\text { accounts, home security monitoring; supervising home repairs; The } \\
\text { following aid for household members who are disabled; care, feeding, } \\
\text { grooming, therapies, care at night, giving special meal, take/ } \\
\text { accompany therapies or medical services, perform formalities, room } \\
\text { cleaning, washing and ironing clothes separately; The following to help } \\
\text { to other households: help with housework, caring people. }\end{array}$ \\
\hline Childcare & $\begin{array}{l}\text { Child feeding, bathing children, play/talk/read stories to children, } \\
\text { practices special exercise or therapy to children, attending meetings/ } \\
\text { festivals/other activities in school, help with homework. }\end{array}$ \\
\hline
\end{tabular}

Source: Time Use Survey of Ecuador 2012 
Table B2 Mexico

\begin{tabular}{ll}
\hline Paid work & Regular work in all jobs, travel from/to all jobs, job seeking \\
\hline Unpaid work & Care for or raise farm animals, caring and sow the orchard, collect/ \\
& carry/store firewood, collecting fruits/mushrooms/flowers, hunting and \\
& fishing for consumption, carry or store water, elaborate or knitting \\
& clothes/tablecloth/curtains/other, threshing corn or prepare tortillas, \\
turn the stove or oven, cooking or preparing food or drinks, heating \\
food or drinks, serve food, washing/drying/accommodate dishes, \\
bringing food to a household member to work or a educative center, \\
cleaning or tidying the house, cleaning the exterior of the house, \\
separate/remove/burn trash, wash/tender/drying clothes, separate or \\
fold the clothes, ironing clothes, mend clothes/tablecloth/curtains, \\
collect or bring clothes and shoes, clean shoes, construction or \\
extension of the home, home repair, appliance repair, carry or supervise \\
appliance repair, wash or clean the vehicle, repair or maintain the \\
vehicle, carry or repair the vehicle, home shopping, purchase \\
construction materials, several purchases as: dishes/tablecloths/ \\
furniture/toys/clothing/footwear, carry or bring to an older person's \\
home for medical care, supervise the construction or repair of the \\
house, buy car/house/apartment, make payments/formalities from \\
home, responsible for accounts/household expenses, protection \\
measures for home, waiting home services like gas; The following aid \\
for household members who are dependent: feeding, bathing or \\
cleaning, administer medications, take them to receive medical \\
attention, give special therapy or exercises; The following to help to \\
other households: help with housework, caring people. \\
Feeding a minor under 6 years, bathing/grooming/dressing a minor \\
under 6 years, bed a minor under 6 years, picking up or dropping of a \\
educative center a minor under 15 years, help with homework a minor \\
under 15 years, attend activities/meetings/festivals in school from a \\
member of household under 15 years, carrying/bringing/accompany a \\
minor under 15 to receive medical attention
\end{tabular}

Source: Time Use Survey of Mexico 2009 
Table B3 Peru

\begin{tabular}{|c|c|}
\hline Paid work & $\begin{array}{l}\text { Regular work in main job, travel to main job, regular work in second } \\
\text { job, travel to second job, job seeking. }\end{array}$ \\
\hline Unpaid work & $\begin{array}{l}\text { Cooking or preparing food, heating food, prepare food in advance, } \\
\text { wash dishes and clean the kitchen, take food to household members to } \\
\text { work or study centre, collect firewood for cooking, lighting firewood } \\
\text { for cooking, prepare pastries for home, making beds and ordering } \\
\text { room, clean the bathroom, general cleanliness of housing, } \\
\text { accommodate and fix housing, tasks related to the trash, carry water for } \\
\text { household consumption, clean or wash vehicles home, laundry, ironing } \\
\text { clothes, accommodate clothing, take clothes to the laundry, shoe care, } \\
\text { mending clothing, home repairs, making housing construction, } \\
\text { appliance repairs, carry appliances repair, care for household members } \\
\text { who are sick, bring the hospital household members who are sick, bring } \\
\text { to receive therapy household members who are sick, prepare home } \\
\text { remedies, buy household items, small household purchases, buying } \\
\text { medicine for home, buy school supplies, buy clothes, buy furniture, } \\
\text { buy spare parts for appliances, buy cars, buy spare parts for cars, carry } \\
\text { household members to work/educational centre, pick up household } \\
\text { members to work/educational centre, farm animal breeding, plant/ } \\
\text { watering/fertilize the orchard, pick fruit or herbs the orchard, carrying } \\
\text { water for the orchard or animals, supervise home repairs, supervising } \\
\text { chores, responsibility for household accounts, several payments, } \\
\text { several formalities, charge government subsidies, responsible for the } \\
\text { safety of home, watch for the delivery of a service in the home such as } \\
\text { gas, paperwork to rent or buy a house; The following aid for household } \\
\text { members who are dependent: cook, clean room, washing/ironing } \\
\text { clothes, feed them, bathing, care during the hours of the night, picking } \\
\text { up or dropping care center/study center, carry health center, practice } \\
\text { therapy; The following to help to other households: cooking, general } \\
\text { cleaning, fetching water, washing and ironing clothes, home repairs, } \\
\text { care of children, sick care, carry medical center, help with shopping, } \\
\text { perform formalities, take to work/educational centre. }\end{array}$ \\
\hline Childcare & $\begin{array}{l}\text { Breastfeed newborn, feeding a baby or child, bathing/dressing } \\
\text { changing diaper a baby or child, play/read stories to a baby or child, } \\
\text { help with homework for a child or teenager, attend activities of an } \\
\text { educational center that assists a child or adolescent who is a member of } \\
\text { the household, therapy practice a baby/child/adolescent }\end{array}$ \\
\hline
\end{tabular}


Table B4 Colombia

Paid work $\quad$ Regular work in main job, travel to main job, regular work in second job, travel to second job, job seeking or formalities to start a business, travel to job seeking or travel to formalities to start a business, travel related to main and second job.

Unpaid work $\quad$ Prepare and serve food, clear the dishes/washing dishes, bring the food to household members to their work/study center, washing/ironing/ store clothes, repairing clothes/tablecloths/blankets/shoes/etc, produce clothes for persons in this household, picking up or dropping clothing/shoes,clean housing, pet care/care garden/clean any household vehicle, bring water for household use, bring fuel (coal, gas, oil) for cooking, build/expand housing, repair/make housing installations, repair appliances/furniture/household vehicles, carry repair appliances/furniture/household vehicles, buy household items, buy or pick up medicines, supervise or direct household activities, pay bills/doing formalities, find housing for rent or purchase, charge government subsidies, displacements to make purchases or formalities, carry or bring any member of this household over 12 years to the study center or at work, carry or bring any member of this household to social/cultural/recreational events, help without pay at a job or business of any member of the household, activities like planting/watering/ fertilize/weeding the orchard, raise animals for consumption of the household, planting/watering/ weeding crops for sale without being paid, raising/hunting/ fishing animals for sale without being paid, mineral extraction without being paid, collect firewood for home, other orchard activities, be aware of household members, feed or assist in feeding to household members from 18 years of age who need help, bathing/dressing to household members from 18 years of age who need help, give medicines/therapies provide/treatment of diseases to household members from 18 years of age who need help, accompany medical appointments or other health care to household members from 18 years of age who need help, carry or bring to medical appointments or other health care to household members from 18 years of age who need help, other activities related to unpaid work; The following to help to other households: help without pay at a job or business, help with household chores, minor home repairs or yard work, build or make any extension of the house, care for children under 12 years who are not ill or are disabled, care for over 60 who are not ill or are disabled, care for sick people, care for the disabled, travel for aid to other households, help with activities like planting/watering/fertilize/ weeding the orchard, raise animals for that household consumption, plant/watering/weeding crops for sale without being paid, raising/ hunting/fishing animals for sale without being paid, extraction of minerals without being paid, gather wood for the household, other activities that orchard.

Childcare $\quad$ Play/read stories/carry to the park to household members under five years of age, carry or bring of a educative center a household member who is 12 years or younger, feed or assist in feeding to minor household members, bathing/dressing to minor household members, give medicines/therapies provide/treatment of diseases to minor 


\section{household members, help with homework to minor household members.}

Source: Time Use Survey of Colombia 2012

Note: The variables considered for childcare comes from two types of questions, direct questions and indirect questions. Indirect questions that aim to know the time spent by respondents to help other household members, these questions given the option of indicating to whom this aid is provided, so that aid to household members under 18 years we considered into the category of childcare, and aid to household members who are 18 years of age or more we considered into the category of unpaid work. Direct questions are: Play/read stories/carry to the park to household members under five years of age, carry or bring of a educative center a household member who is 12 years or younger. Indirect questions are: feed or assist in feeding to household members, bathing/dressing to household members, give medicines/therapies provide/treatment of diseases to household members, help with homework to household members. 